\title{
Rich fen development in CE Europe, resilience to climate change and human impact over the last ca. 3500years
}

Article in Palaeogeography Palaeoclimatology Palaeoecology · February 2017

DOI: 10.1016/j.palaeo.2017.02.030

CITATIONS

0
READS

113

6 authors, including:

\section{Angelica Feurdean}

Senckenberg Biodiversität und Klima - Forschu...

78 PUBLICATIONS $\quad 1,384$ CITATIONS

SEE PROFILE

\section{Piotr Kołaczek}

Adam Mickiewicz University

63 PUBLICATIONS 324 CITATIONS

SEE PROFILE
Simon Mark Hutchinson

University of Salford

71 PUBLICATIONS 818 CITATIONS

SEE PROFILE

Karina Apolinarska

Adam Mickiewicz University

33 PUBLICATIONS 151 CITATIONS

SEE PROFILE

Some of the authors of this publication are also working on these related projects: 


\section{Accepted Manuscript}

Rich fen development in CE Europe, resilience to climate change and human impact over the last ca. 3500years

Mariusz Gałka, Liene Aunina, Angelica Feurdean, Simon Hutchinson, Piotr Kołaczek, Karina Apolinarska

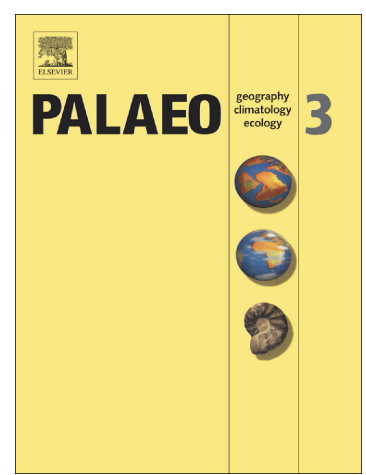

PII:

S0031-0182(16)30668-X

DOI: doi: 10.1016/j.palaeo.2017.02.030

Reference:

PALAEO 8214

To appear in:

Palaeogeography, Palaeoclimatology, Palaeoecology

Received date: $\quad 28$ October 2016

Revised date: $\quad 13$ February 2017

Accepted date: $\quad 14$ February 2017

Please cite this article as: Mariusz Gałka, Liene Aunina, Angelica Feurdean, Simon Hutchinson, Piotr Kołaczek, Karina Apolinarska, Rich fen development in CE Europe, resilience to climate change and human impact over the last ca. 3500years. The address for the corresponding author was captured as affiliation for all authors. Please check if appropriate. Palaeo(2017), doi: 10.1016/j.palaeo.2017.02.030

This is a PDF file of an unedited manuscript that has been accepted for publication. As a service to our customers we are providing this early version of the manuscript. The manuscript will undergo copyediting, typesetting, and review of the resulting proof before it is published in its final form. Please note that during the production process errors may be discovered which could affect the content, and all legal disclaimers that apply to the journal pertain. 
Rich fen development in CE Europe, resilience to climate change and human impact over the last ca. 3500 years

Mariusz Gałka $^{1 *}$, Liene Aunina ${ }^{2}$, Angelica Feurdean ${ }^{3,4}$, Simon Hutchinson $^{5}$, Piotr Kołaczek ${ }^{1}$, Karina Apolinarska ${ }^{6}$

${ }^{1}$ galka@amu.edu.pl, Department of Biogeography and Palaeoecology, Faculty of Geographical and Geological Sciences, Adam Mickiewicz University, ul. B. Krygowskiego 10, 61-680 Poznań, Poland

${ }^{2}$ lsalmina@latnet.lv, Laboratory of Geobotany, Institute of Biology, University of Latvia, Miera Street 3, Salaspils, LV-2169, Latvia

${ }^{3,4}$ angelica.feurdean@gmail.com, Senckenberg Biodiversity and Climate Research Centre (BiK-F), Senckenberganlage, 25, 60325, Frankfurt am Main, Germany; (5) Department of Geology, Babeş-Bolyai University, Kogalniceanu, 1, 400084, Cluj-Napoca, Romania ${ }^{5}$ s.m.hutchinson@salford.ac.uk, School of Environment \& Life Sciences, University of Salford, Salford, M5 4WT, UK

${ }^{6}$ karinaap@amu.edu.pl, Institute of Geology, Faculty of Geographical and Geological Sciences, Adam Mickiewicz University, ul. B. Krygowskiego 12, 61-606 Poznań, Poland

*Corresponding author: galka@amu.edu.pl

\section{Abstract}


Here, for the first time in SE Poland, we document the long-term development of a rich fen and assess its sensivity to climate change and human impacts over the last ca. 3500 years. Our results are based on a high-resolution, continuous plant macrofossil remains, mollusc and pollen record, complemented by geochemical, mineral magnetic and physical characterisation, and radiocarbon dating from Bagno Serebryskie rich fen located in SE Poland. Based on the palaeoecological data we distinguished five stages of wet habitat conditions: 5000-3300, 2800-2150, 1600-1100, 750-230, 150-10 cal yr BP and five dry periods at ca. 3300-2800, 2150-1600, 1100-750, 230-150, 10 to -64 cal yr BP. The pollen and geochemistry records, particularly $\mathrm{Pb}$, show that the first human activity in the study area occurred ca. 3200 cal yr BP and increased markedly from 500 cal yr BP affecting local plant development including the population size of Cladium mariscus. Our study has shown that despite human impact (drainage, fire), Bagno Serebryskie peatland has hosted rare, presently protected species, such as Cladium mariscus for hundreds of years. We conclude that, in common with ombrotrophic bogs, rich fen ecosystems can provide a reliable source of palaeoclimatic and palaeohydrological data. Our study also shows that a large peatland (376 ha) can be as sensitive a palaeohydrological archive as smaller mires.

\section{Keywords}

Plant macrofossils, pollen, Cladium mariscus, molluscs, geochemistry, calcareous fen

\section{Introduction}

Rich fens are among one of the most important wetland ecosystems; occupied by endangered, vulnerable and protected plant communities (Grootjans et al., 2006). The development of rich fens depends primarily on the supply of minerotrophic water carrying nutrients from the catchment soils and rocks. Rich fens are not only fed by groundwater but 
also by rainfall. In contrast to poor fens and bogs, waterlogged rich fens are species-rich, with vegetation dominated by Cyperaceae (e.g. Carex, Cladium, Schoenus) and bryophytes (e.g. Campylium, Scorpidium, Calliergonella) (Slack et al., 1980; Hájek et al., 2006). Studies focusing on various aspects of recent rich fens, including their ecology, the distribution of plants and restoration have been carried out (Salmina, 2004; Mälson and Rydin, 2007; Ilomets et al., 2010; Kotowski et al., 2013; van Diggelen et al., 2015).

Effective management strategies to protect or restore rich fens require adequate knowledge of the development of these threatened wetland ecosystems (Seddon et al., 2014; Clarke and Lynch, 2016). The history of fens has been described in various studies (e.g.

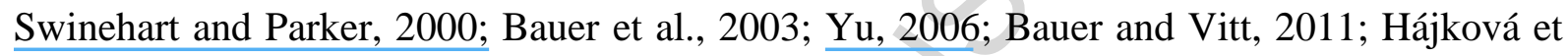
al., 2013; Lamentowicz et al., 2013; Gałka et al., 2016a), however, knowledge of the drivers of the rich fen development is lacking. Multi-proxy palaeoecological studies aiming to reconstruct the internal and external drivers of the development of rich fens in Central Europe have only been undertaken at the Stążki rich fen site in the lowlands of northern Poland (Lamentowicz et al., 2013), in Male Bielice, a mountainous area in the Western Carpathians, Slovakia (Hájková et al., 2013) and at Apšuciems Mire, an extremely rich fen in a dune area on the southeastern Baltic coast of Latvia (Gałka et al., 2016a). These studies have shown that changes in plant succession in rich fens ecosystems are complex and can be linked to climatic changes, human impacts and internal aspects of these ecosystems.

Our palaeoecological study focuses on the development of Bagno Serebryskie (BS) rich fen (ca. $376 \mathrm{ha}$ ), one of the largest peatlands in Central Europe and developed in an outflow depression in a karst area. In this study we aim to reconstruct the response of this rich fen to climate change, human impacts and fire during the late Holocene. To accomplish this aim a high resolution $(1-3 \mathrm{~cm})$, multi-aspect palaeoecological analysis (plant macrofossils, pollen, molluscs, geochemistry, mineral magnetic and physical property characterisation, 
macrocharcoal and ${ }^{14} \mathrm{C}$ dating) of two peat profiles from BS was undertaken. Furthermore, the site has one of the largest populations of Cladium mariscus L. (Pohl) in Central East Europe (CE Europe); a rare, endangered, and vulnerable plant in rich fen ecosystems (Gałka and Tobolski, 2012; Hájková et al., 2013). The study area is located at the current eastern range limit of $C$. mariscus in Europe, which makes it particularly sensitive to changes in climatic conditions, and therefore a potentially promising bioindicator. The species has previously been observed to be a good indicator of warm climate phases (cf. Berglund, 1968; Walter and Straka, 1970). The main objectives of this study are: i) to determine the influence of allogenic (climate change and human impact) and autogenic drivers of rich fen development over the late Holocene; ii) to identify the factors responsible for the spread of $C$. mariscus, presently one of the common plants on this peatland; iii) to define the variability in local vegetation development by using two parallel peat cores as replicates. This approach is rarely employed in palaeoecological studies, and mainly in ombrotrophic peatlands (Lamentowicz et al., 2011; Gálová et al., 2016; Gałka et al., 2016a), but it is crucial for the validation of paleoenvironmental interpretations, especially for testing the impact of recent climate change on local vegetation in different parts of peatlands (Charman et al., 1999). We hypothesise that i) the studied rich fen responded sensitively to both late Holocene climatic fluctuations and the intensification of human activity, including deforestation, fire and pollution, and ii) past climate variability of the late Holocene (warm and cold phases) significantly affected the range distribution and abundance of the population of $C$. mariscus at the study site. Our palaeoecological approach will contribute to a better ecological and biogeographic understanding of rich fens and will improve the assessment of potentially sensitive areas for C. mariscus to future environmental change. 
In our study, we use the term rich fen in accordance with the European Nature Information System habitat classification (EUNIS, http://www.eunis.eea.europa.eu/); rich fens are assigned to type D4.1: rich fens, including eutrophic tall-herb fens and calcareous flushes and soaks (Davies et al., 2004).

\section{Study site}

Bagno Serebryskie peatland (ca. 376 ha), protected as a nature reserve since 1991, is located in southeastern Poland in the northern part of the Chełm Hills subregion of the Lublin Upland (170-220 m a.s.l., Fig. 1). The peatland developed in a closed sinkhole; a common geomorphological landform in this karst area (Wojtanowicz, 1994; Dobrowolski et al., 2015). During the Late Glacial and early Holocene many of these sinkholes functioned as shallow lakes as evidenced by the presence of calcareous gyttja below the peat deposits (Aleksandrowicz et al., 1994; Buczek, 2005; Dobrowolski et al., 2015). The Chełm Hills subregion was glaciated at least twice (Elsterian and Saalian), but was not directly affected by the last glaciation (Weichselian). Quaternary deposits accumlated directly on Upper Cretaceous carbonate rocks i.e. limestones, marls and chalk (Krassowska and Niemczycka, 1984); including sands, gravels and diamictons of Saalian glaciogenic origin, Weichselian fluvial and limnic periglacial sands and silts, and Holocene peat, gyttja and muds.

The climate of the area is continental, with a mean annual temperature of $8{ }^{\circ} \mathrm{C}$, a mean July temperature of $17.5^{\circ} \mathrm{C}$ and a mean January temperature of $-3.5^{\circ} \mathrm{C}$. Annual precipitation averages $550 \mathrm{~mm}$ (Lorenc, 2005).

In the northern, wetter part of the peatland, where the sampled sites are located, Cladium mariscus was a dominant plant species at the time of field sampling. The vegetation also included Phragmites australis, Mentha aquatica, Lythrum salicaria, Utricularia intermedia and Carex elata. In the marginal, drier parts of the peatland, adjacent to the $C$. 
mariscus community, Carex hostiana, Carex buxbaumii, Salix rosmarinifolia, Schoenus ferrugineus, Epipactis palustris, and Sanguisorba officinalis were found. Among the mosses present Campylium stellatum, Scorpidium cossonii, and Bryum pseudotriquetrum were noted.

Agriculture dominates in the vicinity of the peatland. To the west and northwest the peatland is bordered by coniferous and broad-leaved deciduous forests (Fig. 1). The Chełm cement factory, established in 1960, is located to the south of the peatland (ca. $4 \mathrm{~km}$ from the sampling site). A railway line crosses the southern part of the BS peatland (Fig. 1). In contrast to other large peatlands located in the Chełm area, BS has only been partly drained (the northeastern part).

\section{Material and methods}

\subsection{Field work and core sampling}

Two cores located ca. $700 \mathrm{~m}$ apart, were extracted using a Russian-type peat corer (7 $\mathrm{cm}$ in diameter and $100 \mathrm{~cm}$ in length) from a surface overgrown by Cladium mariscus populations. The first, $127-\mathrm{cm}$ long core (BSI) was retrieved from the southern part and the second, 120-cm long core (BSII), from the south-eastern part of the peatland (Fig. 1). At both core sites the water level table was found at ca. $10-11 \mathrm{~cm}$ above the peatland surface. The cores were individually wrapped and stored at $4{ }^{\circ} \mathrm{C}$ until subsampling. One-cm thick sediment layers were sampled continuously for plant macrofossils (BSI and BSII) and mollusc (BSII) analysis, at 2-cm intervals for pollen analysis (BSII) and at $3 \mathrm{~cm}$ intervals for geochemical analysis (BSI).

We used the nomenclature of Mirek et al. (2002) for vascular plants and Hill et al. (2006) for bryophytes. .

\subsection{Laboratory work}

\subsubsection{Chronology}


Five AMS (Accelerator Mass Spectrometry) radiocarbon dates measured on plant macrofossils hand-picked during plant macrofossil analysis and bulk samples were used to provide chronology for the core BSIwith seven AMS dates for core BSII (Table 1).

Calibration of the radiocarbon dates and the construction of Bayesian age-depth models was performed with OxCal 4.2 software (Bronk-Ramsey, 2009) with the application of the IntCal13 (Reimer et al., 2013) and post-bomb NH1 (Hua et al., 2013) atmospheric curves. The age-depth models were calculated using the $P_{-}$Sequence function $\left(k_{0}=1 \mathrm{~cm}^{-1}\right.$; interpolation: 0.5-cm resolution, $\log _{10}\left(k / k_{0}\right)=1$; Fig. 2). The most distinct changes in peat composition, which might be a signal of changes in peat accumulation rate, were introduced to the models using the Boundary command. For a greater readability of the article, $\mu$ value (a mean value of the modelled age) was selected as this reflects the modelled age, which was expressed as cal yr BP (years before AD 1950, 0 cal yr BP = AD 1950). All dates were rounded to tens.

\subsubsection{Plant macrofossil analysis}

Plant macrofossils were analysed at $1-\mathrm{cm}$ (core BSII) and mainly $2-\mathrm{cm}(1 \mathrm{~cm}$ thick slices, core BSI) intervals in samples of approximately $16-18 \mathrm{~cm}^{3}$, totalling 187 samples. For further detailed information on the plant macrofossil analysis see Gałka et al. (2016a). The volume percentages of the different vegetative remains were estimated to the nearest $5 \%$ (Gałka et al., 2013; Lamentowicz et al., 2013). Numbers of seeds, fruits, and leaves were counted separately using a stereoscopic microscope. Macroscopic charcoal pieces (> 1mm) were also counted during plant macrofossils analysis and their presence provides information on past local fire occurrence (Mooney and Tinner, 2011). The ecological requirements of several key plant species (Ellenberg et al., 1991; Zarzycki et al., 2002) were used to distinguish wet and dry phases in the peatland development. 


\subsubsection{Pollen analysis}

Fifty nine samples, each $1 \mathrm{~cm}^{3}$ in volume, were prepared for pollen analysis using standard preparation procedures (Berglund and Ralska-Jasiewiczowa, 1986). The pollen taxa were identified with the assistance of the modern pollen slide collection of the Institute of Geoecology and Geoinformation AMU in Poznań as well as keys and atlases (e.g. Moore et al., 1991; Beug, 2004). The pollen percentages were calculated according to the formula: taxon percentages $=$ number of taxon grains $/$ TPS $\times 100 \%$, in which TPS means total pollen sum including pollen of arboreal (AP) and non-arboreal (NAP) taxa, excluding local taxa i.e. aquatic, wetland, and spore-producing ones. Pollen indicators of human activity were divided into those characteristic of cultivated land, including Cerealia types, Secale cereale, Triticum type and Fagopyrum, and taxa associated with pastures, meadows and ruderal areas (Plantago lanceolata, Artemisia, Asteraceae, Urtica, Rumex acetosa-acetosella) (Behre, 1981).

\subsubsection{Molluscs}

After selection of the macrofossil remains, the sediment samples from BSII were examined for mollusc shells. The molluscs were hand-picked and identified under a lowpower binocular microscope (Zeiss Stemi 2000-C) using reference collection of Institute of Geology AMU in Poznań and keys and atlases (Ložek, 1964; Piechocki, 1979; WelterSchultes, 2012). The results are expressed as the number of specimens of each taxon in each sample.

\subsubsection{Environmental magnetism, geochemical analysis and physical properties}

Sub-samples from core BSI were dried in a fan oven at ca $40{ }^{\circ} \mathrm{C}$ and the dried material disaggregated by mortar and pestle prior to sample characterisation. 
A suite of mineral magnetic measurements were made with samples tightly packed into 10 $\mathrm{cm}^{3}$ plastic pots: low field mass specific magnetic susceptibility ( $\left.\chi \mathrm{lf}\right)$ using a Bartington Instruments Ltd. MS2B sensor; anhysteretic remanent magnetisation (ARM); saturation remanent magnetisation (SIRM). ARM was imparted to the samples in a Molspin AF demagnetiser with a maximum field $100 \mathrm{mT}$ and a steady bias field $0.04 \mathrm{mT}$. SIRM was imparted in a Molspin pulse magnetiser in a field of $1 \mathrm{~T}$. Reverse field magnetisation in fields $-20 \mathrm{mT},-40 \mathrm{mT},-100 \mathrm{mT}$ and $-300 \mathrm{mT}$ followed. The magnetic remanence of samples was measured in Minispin fluxgate magnetometer. Results are expressed on a sample mass basis. (Hutchinson, 1995; Akinyemi et al., 2013).

Trace element concentrations were determined by fpXRF (field portable X-ray fluorescence) using a Niton XL3t GOLDD analyser. Samples were placed in cups fitted with a $6 \mu \mathrm{m}$ thick polyester film which provides a thin film sample window. NCS DC73308 was used as a Certified Reference Material (CRM). The duration of each reading was four minutes and the detector analysed the presence of 30 elements. The instrument's performance is discussed by Shuttleworth et al. (2014).

The organic content of samples was determined by loss on ignition (LOI). This was performed in a muffle furnace at a temperature of $550{ }^{\circ} \mathrm{C}$ (four hours) although this parameter should be seen as a guide only to the organic content (Heiri et al., 2001) and as a qualitative proxy (Santisteban et al., 2004).

The particle size distribution of ashed samples was determined using a Horiba Laser Particle Size Analyzer (Partica LA-950) in order to charcterise the minerogenic particulate matter held within the profile. This instrument complies with ISO 13320 (Particle size analysis - Laser diffraction methods) with a documented accuracy of $3 \%$ on the median of broad-distribution standards with a precision of $0.1 \%$. Repeat measurements (3 times) of each sample 
performed (after 1 min of ultrasonication) in order to minimise uncertainties (Haliuc et al., 2016).

\subsubsection{Statistics and presentation of data}

We performed detrended correspondence analysis (DCA) in order to summarise the main compositional trends in the plant macrofossil assemblages in the two parralle cores (BSI and BS II) and to determine whether this has proceeded in a similar way at the two coring points. DCA was performed on square root transformed percentage data using PAST and shows that the longest gradient is length larger than two SD (3.1) (Hammer et al., 2001). The results of the plant macrofossil, charcoal, mollusc, and geochemical analyses were presented in the form of diagrams drawn with the C2 graphics program (Juggins, 2003). The results of pollen analysis are presented in the form of diagrams, divided into zones by the CONISS method and drawn with the Tilia graphics program (Grimm, 1992).

\section{Results}

\subsection{Lithology, chronology, and peat accumulation rate}

In both cores the lowermost sediments consist of detritus gyttja lying between 137 and $120 \mathrm{~cm}$ (ca. 4000-1900 cal yr BP) in core BSI and between 130 and $120 \mathrm{~cm}$ (ca. 5000-3600 cal yr BP) in core BSII (Fig. 2). These lacustrine sediments are overlaid by herbaceous peat composed mainly of the remains of Cyperaceae. In core BSI the peat has accumulated since ca. $1800 \mathrm{cal}$ yr BP and in BSII since ca. $3600 \mathrm{cal}$ yr BP. The average peat accumulation rate (PAR) in both cores was rather low at $0.6 \mathrm{~mm} / \mathrm{year}^{-1}$ in core BSI and $0.32 \mathrm{~mm} / \mathrm{year}^{-1}$ in core BSII. In the uppermost $40 \mathrm{~cm}$ of both cores PAR increased to $0.86 \mathrm{~mm} / \mathrm{year}^{-1}$. 


\subsection{Plant macrofossils}

The DCA axis 1 scores of cores BS I and BSII show distinct compositional changes at the main zone boundaries. Most important shifts occurred ca. 1800, 1150, 880, 450, -45 cal yr BP in core BSI, and ca. 3550, 1500, 800, $200 \mathrm{cal} \mathrm{yr} \mathrm{BP} \mathrm{in} \mathrm{the} \mathrm{core} \mathrm{BSII} \mathrm{(Figs.} \mathrm{3A} \mathrm{and} \mathrm{3B).}$

Five zones in local vegetation development were delimited using the main changes indicated by DCA anaylsis in both core BSI and BSII supported by the DCA analysis (Fig. 3A). The first zone (BSI-ma-1; ca. 4000-1800 cal yr BP) records a shallow lake stage indicated by macrofossils of aquatic plants such as Ceratophyllum submersum, Potamogeton natans, Potamogeton lucens, Lemna minor, Chara sp. and Stratiotes aloides. Two pieces of macrocharcoal were also noted. Zone BSI-ma-2 (ca. 1800-1150 cal yr BP) is characterised by rare Chara sp. oospores and Menyanthes trifoliata seeds. One Cladium mariscus seed was found at ca. 1320 cal yr BP. In BSI-ma-3 (ca. 1150-880 cal yr BP) Mentha aquatica and Alisma plantago-aquatica appeared for the first time. During the zone (BSI-ma-4; ca. 880-100 cal yr BP) Chara sp. and Menyanthes trifoliata was recorded once more. In BSI-ma-5 (ca. 100 to -64 cal $\mathrm{yr} \mathrm{BP})$ the continuous presence of $C$. mariscus and numerous fruits of Carex, e.g. C. hostiana, C. flava and C. lasiocarpa were documented. Macrocharcoal particles were also present.

The oldest zone (BSII-ma-1; ca. 5000-3500 cal yr BP) records a shallow lake stage indicated by individual macrofossils of Myriophyllum verticillatum, Potamogeton gramineus, P. natans and abundant oospores of Chara sp. (Fig. 3B). Two macrocharcoal fragments were also found. In the zone BSII-ma-2 (ca. 3500-1500 cal yr BP) numerous oospores of Chara sp. were recorded, which disappeared in the upper part of this zone. One C. mariscus seed at ca. $2500 \mathrm{cal}$ yr BP was also found. Chenopodium cf. album and Mentha aquatica were dominant in the lower part of zone BSII-ma-3 (1500-800 cal yr BP) and were followed by Carex lasiocarpa in the upper part of this phase. About 1000 cal yr BP numerous macrocharcoals 
were recorded. Zone BSII-ma-4 (800-200 cal yr BP) was characterised by the continuous presence of Chara sp. and C. mariscus from 450 cal yr BP onwards. Macrocharcoals were also present. In zone BSII-ma-5 M. aquatica was recorded, whereas $C$. hostiana and $C$. flava appeared for the first time. Within this zone numerous $C$. mariscus seeds were present. In the upper part of this zone macrocharcoals were also recorded.

\subsection{Pollen}

Seven zones reflecting regional and local vegetation development were numerically delimited in core BSII (Fig. 4). Zone BSII-po-1 (ca. 5000-3500 cal yr BP) was characterised by the dominance of Betula and Pinus sylvestris type pollen; with a peak in Betula of up to $50 \%$ followed by a peak in Pinus sylvestris of up to $65 \%$. Pollen of aquatic plants such as Myriophyllum verticillatum/spicatum, Nymphaea alba, and Potamogeton subgen. Eupotamogeton were present, whereas among the algae, Botryoccocus revealed the highest percentages in the profile. In zone BSII-po-2 (ca. 3500-2550 cal yr BP) there was a decreasing trend of P. sylvestris type and Betula pollen with an increased presence of temperate tree taxa such as Quercus, and Carpinus betulus as well as Alnus. In the bottom part of this zone, percentages of Poaceae and Sparganium t. increased and afterwards decreased, whereas in the middle part (ca. 2900 cal yr BP) Cyperaceae undiff. recorded an increase. Aquatic non-pollen palynomorphs (NPPs) HdV-128B became more numerous and regular. In zone BSII-po-3 (ca. 2550-2150 cal yr BP) a significant decrease in P. sylvestris t. and an increase in Betula (up to $60 \%$ ) took place. Pollen percentages of Cyperaceae undiff. decreased. Single pollen grains of cf. Cladium mariscus, Utricularia, and Sparganium t. were recorded. Zone BSII-po-4 (ca. 2150-1500 cal yr BP) revealed the increased presence of P. sylvestris t., Quercus and Cyperaceae undiff., whereas Secale cereale appeared for the first time. Zone BSII-po-5 (ca. 1500-600 cal yr BP) was characterised by an almost constant share of Betula, Quercus, Alnus 
and Pinus sylvestris and the highest values of Cyperaceae undiff. (max. $60 \%$ ) in the entire sediment sequence. In zone BSII-po-6 (ca. 600-200 cal yr BP) the frequency of cultivated plants and C. mariscus increased. Zone BSII-po-7 (ca. 200- -64 cal yr BP) revealed a decrease in the pollen of deciduous trees and dominance of $P$. sylvestris type. Percentages of cultivated plants were their highest in the profile. HdV-128A occurred regularly and its percentages were the highest in the profile. In the topmost section of this zone the frequency of coprophilous fungi and $\mathrm{HdV}-126$ increased; C. mariscus was also regular.

\subsection{Molluscs}

Six phases of mollusc presence were visually delimited in core BSII (Fig. 5). In the first phase BSII-mo-1 (ca. 5000-3400 cal yr BP) 18 species typical of the shallow littoral zone of lakes were distinguished, among them Valvata piscinalis, Valvata cristata, Gyraulus crista, Bithynia tentaculata, and Pisidium sp. were dominant. Phase BSII-mo-2 (ca. 2750-2550 cal yr BP) is characterised by the occurrence of a few shells of 12 species with the regular presence of Gyraulus leavis, V. cristata, and Pisidium sp. In phase BSII-mo-3 (ca. 2450-2150 cal yr BP) taxonomical diversity of molluscs increased to 18 species. The highest density of mollusc occurred at ca. 2300 cal yr BP and was dominated by B. tentaculata, V. cristata, Pisidium sp., Gyraulus riparius, and Omphiscola glabra. In the first half of phase BSII-mo-4 (ca. 15501050 cal yr BP) B. tentaculata, Planorbis planorbis, Glabra truncatula, and Succineidae were the dominant species, whereas in the second half the increasing role of G. crista, V. cristata, G. riparius and P. planorbis was recorded. In this fourth phase Succinea putris, Euconulus fulvus, Viviparus sp., and Anisus septemgyratus appeared for the first time. Phase BSII-mo-5 (ca. 800-300 cal yr BP) is cha-racterised by the presence of 13 species among which $B$. tentaculata, Pisidium sp., P. planorbis, and G. truncatula dominated. In the middle part of phase BSII-mo-5, at ca. 500 cal yr BP, mollusc populations declined for a short time. Radix 
labiata and Vertigo antivertigo appeared ca. 400 cal yr BP. In phase BSII-mo-6 (ca. 200 to 64 cal yr BP) 16 mollusc species were present, amongst them three new taxa in the sequence studied appeared: Carychium tridentatum, Vallonia pulchella, and Carychium minimum. Since ca. 40 cal yr BP mollusc biodiversity has decreased.

\subsection{Environmental magnetism, geochemical analysis and physical properties}

The organic content of core BSI rapidly increases above the base of the profile with values generally around $75 \%$ throughout the core apart from the section with the lowest levels between 1350 and $1250 \mathrm{cal}$ yr BP. From $1000 \mathrm{cal}$ yr BP LOI values remain relatively steady (Fig. 6). The median particle size of the mineral fraction of the profile shows a generally inverse relationship with the organic content; median particle size values are highest (around $80 \mu \mathrm{m})$ at the base of the core, described as detritus gyttja, and between 1950 and $950 \mathrm{cal} \mathrm{yr}$ BP formed by peat.

Two mineral magnetic parameters have been selected to represent core BSI's features : $\chi$ lf and SIRM/ARM (Fig. 6). They provide an overview of both mineral magnetic concentration and grain size. The $\chi \mathrm{lf}$ is very low throughout most of the profile, which is a common feature in peat, rising slightly in more recent centuries then markedly above $20 \mathrm{~cm}$ (45 cal yr BP) with a marked subsurface peak in concentration. The SIRM/ARM ratio indicates variations in mineral magnetic grain size; its profile is more variable, but this quotient is elevated in the lake sediment phase (basal) part of the core and the uppermost layers, where magnetic concentrations peak, indicating a greater and coarser input of mineral magnetic assemblages. Figure 6 also illustrates the profiles of selected trace elements including those of lithogenic and potentially anthropogenic origins. A common trend is for a significant peak in concentration towards the surface of the core. Lithogenic indicators such as $\mathrm{Zr}, \mathrm{Rb}$ and $\mathrm{Ti}$ show modest increases in both the lowest part of the core (ca. 4000-1950 cal 
yr BP) and the section where median particle rises (1950-950 cal yr BP). After 850 cal yr BP the intial rise in $\mathrm{Pb}$ level, and other elements associated with human activity (e.g., $\mathrm{As}, \mathrm{Zn}, \mathrm{Cu}$ ) took place. These concentration peaks are most marked in the last several decades of peat accumulation. However, the Fe/Mn profile, with a sharp peak around 20-15 cm depth, highlights the potential for the post depositional modification of both trace element and mineral magnetic profiles. Fe and $\mathrm{Mn}$ are their high sensitivity to geochemical changes in the depositional environment and their ratio can be used as a proxy for palaeo-redox conditions.

\section{Discussion}

\subsection{Rhythmic mollusc occurrence at Bagno Serebryjskie rich fen}

The most characteristic feature of the BSII sequence is the rhythmic appearance and disappearance of mollusc shells over the past 3400 years (Fig. 5.) In order to explain this rhythmic occurrence we need to consider both the factors controlling the presence of mollusc species in peatland and the post-depositional processes influencing shell preservation. In general, the mollusc assemblages occurring within the sequence studied comprise mostly aquatic species indicative of standing waters, or at least small water pools on the peatbog, and snail species typical of the damp habitat transitional between water and land. The repeated retreat of aquatic molluscs observed could be influenced by decreases in groundwater. However, the process of the peatbog terrestrialisation will be reflected in the succession of land species as water levels decrease (Alexandrowicz, 2007, 2013). The absence of semiterrestrial and terrestrial species during low water stands (when aquatic molluscs are absent) may have resulted from a decrease in the calcium levels of the peatland as this mineral is essential, not only for the shell growth, but also for physiological processes (Wäreborn, 1970) and is regarded as the most important macronutrient for land snails (Dallinger et al., 2001). In recent studies of fens the number of snail species drops with a 
lower carbonate content in groundwaters and the decreased $\mathrm{pH}$ of the habitat (Horsák and Hájek, 2003). Only a few species are adapted to acidic conditions (Horsák and Cernohorsky, 2008). However, presence of mollusc shells in sediments is controlled not only by ecological conditions, , but also by , post-depositional processes. Optimal fossilisation conditions for shells occur within calcareous sediments (Ložek, 2000). In sediments with a low $\mathrm{CaCO}_{3}$ content and a high proportion of organic matter shells can be dissolved, probably within less than one year (Cernohorsky et al., 2010). A decreased calcium and dissolved carbonates content at the study site can be explained by changes in climate humidity and the resulting decreased supply of alkaline groundwater, mineral-rich due to dissolution of the Upper Cretaceous carbonate bedrock (Krassowska and Niemczycka, 1984). Decreased precipitation and a resulting fall in groundwater levels the importance of rainwater supply to peatland increased what further decreased the dissolved carbonate content and $\mathrm{pH}$ at the peatbog surface. Such changes affected the mollusc population by decreasing its variability and abundance, and the fossilization potential of the empty shells. The precipitation of $\mathrm{CaCO}_{3}$ in the peatland is also influenced by the difference between the temperature of the groundwater and that of the air. Increases in the calcium carbonate content of spring-fed fen sediments are commonly linked with a warmer climate (e.g. Dobrowolski et al. 2016). The reasons of mollusc absence at particular intervals are discussed below along with an interpretation of peatland development at BS over the last 3400 cal yr BP.

\subsection{Drivers of rich-fen development: palaeohydrology and climatic implications}

The following discussion deals with the history of the Bagno Serebryjskie rich fen based on plant macrofossil, mollusc, pollen and geochemical recordsfrom ca. 5000 to -64 cal yr BP. The past climate and local hydrological changes inferred from our paleoecological 
data are discussed as the main drivers of development of the fen. We distinguish ten hydroclimatic stages in the development of the Bagno Serebryskie peatland (Fig. 7).

\subsubsection{Transition from lake to peatland (stages $A$ and B, ca. 5000-2800 cal yr BP)}

The two potential driving forces of the formation of $\mathrm{BS}$ rich fen were terrestrialisation (the in-filling of the lake with the sediments) and the lowering of the lake level during a warm and /or dry climatic stage. The terrestrialisation process and initiation of peatland formation was diachronous at the two sampling sites. In core BSII the transition from gyttja to peat was dated at ca. $3500 \mathrm{cal} \mathrm{yr} \mathrm{BP}$, whereas in core BSI the change to a telmatic environment was delayed until ca. 1800 cal yr BP. Macrofossils of aquatic plants typical of a shallow littoral zone e.g. Potamogeton natans, Nymphaea alba, and numerous Chara sp. oospores are common in the final stage of the lake in both cores (Hannon and Gaillard, 1997). In addition, in BSII core Schoenoplectus lacustris and Typha sp. macrofossils and Sparganium pollen, common indicators of the transitional zone between lake and peatland (Hannon and Gaillard, 1997) were recorded. Gradual shallowing of the site is further indicated by the change in mollusc assemblages (Figs 5, and 7) that shifted from species typical of permanent lakes, i.e. Bithynia tentaculata and Valvata cristata, to taxa found in shallow littoral zones and temporarily dry sites i.e. Lymnaea stagnalis and Planorbis planorbis (Piechocki, 1979). An abrupt disappearance of aquatic mollusc populations, a decreased share of Chara sp. oospores and an increase of Cyperaceae in core BSII ca. 3400 cal yr BP signal a lowering of the water level of the lake. Changes in mollusc and local plant communities coincided with the gradual spread of species typical of damp habitats, Alnus and the moderate spread of Fraxinus excelsior and Salix, which perhaps grew in the vicinity of shallow lakes and wet depressions in this karst area. Despite the clear lowering of the water level since ca. 3400 cal yr BP, the presence of small pools on the fen until ca. $2800 \mathrm{cal} \mathrm{yr} \mathrm{BP}$ is indicated by constant presence 
of Botroycoccus and Chara sp. and the significant share of Tetraedron minimum (Fig. 7). Although both Botroycoccus and Chara sp. are linked to aquatic habitats, they do not require a permanent water presence throughout the year. In Sphagnum peatland in northern Poland the presence of Botroycoccus has been correlated with dry phases (Marcisz et al., 2016). It was suggested that this green alga may develop during the spring (after a winter thaw) although during the following summer conditions may be dry. Some of the species within the genus Chara grow in very shallow i.e., a few $\mathrm{cm}$ deep, small water pools within peatlands, e.g., Chara delicatula (Pełechaty and Pukacz, 2008) and also do not require a permanent water presence through out the vegetative season. Thus we suggest a general shift towards drier conditions at BS between ca. 3500 and 2800 cal yr BP resulting in a decreased supply of calcium and carbonate ions to the bog surface. Preservation of all mollusc shells, whether aquatic, semiterrestrial or land species, under conditions unfavorable for $\mathrm{CaCO}_{3}$ precipitation at the peatland was therefore unlikely.

\subsubsection{Wet stage (stage C, ca. $2800-2150$ cal yr BP)}

Re-appearance of mollusc species typical of permanent water bodies, i.e. Valvata cristata and Gyraulus leavis (Piechocki, 1979) is linked with improved conditions for $\mathrm{CaCO}_{3}$ precipitation and shell preservation resulting from an enchanced supply of mineral-rich groundwaters and an increased water level at BS rich fen at ca. $2800 \mathrm{cal} \mathrm{yr}$ BP. A higher water level is also supported by the presence of Utricularia (pollen), an aquatic plant occurring in shallow lakes, small depressions in peatlands or shallow water-logged basins (Hannon and Gaillard, 1997). The increase in the water table in the fen since ca. $2800 \mathrm{cal} \mathrm{yr}$ BP resulted in a reduced number of plants from the Cyperaceae family, which were partly replaced by plant communities of Equisetum fluviatile a species occurring in shallow lakes 
(Hannon and Gaillard, 1997). These changes in vegetation and mollusc assemblages coincide with the $2.8 \mathrm{ka}$ cold event (Swindles et al., 2007; Wanner et al., 2011), characterised by climate cooling and increased humidity linked to decreased solar activity (van Geel et al., 1996). Increased humidity around 2800 cal yr BP was indicated by higher rates of peat accumulation in ombrotrophic peatlands in western Europe (van Geel et al., 2014), rising lake levels and water levels in peatlands in central Europe (Magny, 2004; Feurdean et al., 2013; Słowiński et al., 2016) and increases in fluvial activity in Poland (Starkel et al., 2013). In the Lublin Upland, increased humidity between ca. 2700 and 2000 cal yr BP was observed at Komarów spring-fed fen (Dobrowolski et al., 2016). This wet and cold period was recorded in core BSII until ca. 2150 cal yr BP as indicated by an almost constant presence of mollusc shells and Chara sp. oospores (Fig. 7). A short-term lowering of the water table was recoded between ca. 2550 and 2450 cal yr BP by the decreased preservation of mollusc shells, concurrent with occurrence of Cladium mariscus seeds and pollen. However, this short-term lowering of the water table favoured the expansion of Betula trees in the surrounding of the peatland ca. 2600-2150 cal yr BP. This may be linked to increased contentality i.e., warmer and drier summers. A subsequent return to cooler climatic conditions is suggested by a drop in pollen percentages of Cyperaceae at ca. $2250 \mathrm{cal}$ yr BP and a significant reduction in mollusc shells. This climate cooling corresponds to the cooler period and wave of human migration known as the Celtic Expansion (Büntgen et al., 2011).

\subsubsection{Dry stage (stage $D$, ca. $2150-1600$ cal yr BP)}

The dissaperance of molluscs from the fossil record, the increased abundance of Cyperaceae (pollen) and the development of plant communites with Cladium mariscus (pollen and plant macrofossils) at this time is indicative of the lowering of the water table of the peatland (core BSII). More widespread drying in southeastern Poland is indicated by the 
decreased humidity observed at Komarów spring-fed fen (Lublin Upland) from 2000 cal yr BP (Dobrowolski et al., 2016), which partly correspond to our palaeohydrological data. Drier conditions at BS peatland are further indicated by the increase in corroded pollen and fungi remains (Fig. 4). However, periods of, at least temporary, water stagnation/and or an increased water table are indicated by the constant presence of Botryococcus (Kołaczek at al., 2015; Gałka et al., 2016a; Marcisz et al. 2016), Mougeotia sp. and HdV-128B (van Geel et al., 1981). This dry stage of the peatland, recognised in core BSII, is concurrent with the transition from lake to the rich fen recorded in the core BSI (Fig. 3A). The dry period recorded between 2150 and 1600 cal yr BP coincides partly with the warm Roman Period (Büntgen et al., 2011; PAGES 2k Consortium, 2013). Greater human activity in the surroundings of the peatland during this period is visible in the increase in pollen of cultivated plants including Secale cereale and Cerealia type. (Fig. 4). However, there was no significant deforestation that could have resulted in any subsequent alteration to the water table of the mire.

\subsubsection{Wet stage (stage E, ca. $1600-1100$ cal yr BP)}

The next significantly higher water level at the peatland was documented between ca. 1600 and 1100 cal yr BP by the increased abundance of mollusc shells and the decrease in Cyperaceae pollen (Fig. 7). The highly diversified and numerous mollusc assemblage during the wet stage $\mathrm{E}$ indicates a long-standing increase in the water level favourable for both the development of a mollusc population and subsequent shell preservation, in contrast to the other wet stages where a discontinuous mollusc presence indicates fluctuations in the water level. The first half of this stage coincides with the colder and wetter Migration Period (Büntgen et al., 2011; PAGES 2k Consortium, 2013), which caused turmoil in Europe. High water levels were recorded from ca. $1600 \mathrm{cal}$ yr BP in lakes from central Europe (Magny, 
2004) and in several ombrotrophic peatlands in the Baltic Sea region (Barber et al., 2004; Väliranta et al., 2007; Lamentowicz et al., 2015). In the second half of the stage (from ca. 1300 cal yr BP), the water level in BS peatland may have been gradually decreased as suggested by the appearance of Mentha aquatic and increased Carex communities (pollen and macrofossils).

\subsubsection{Dry stage (stage $F$, ca. 1110-750 cal yr BP)}

Lowering of the mire's water level since ca. $1100 \mathrm{cal}$ yr BP is indicated by a reduction in the mollusc shell numbers, their subsequent disappearance from ca. $1000 \mathrm{cal}$ yr BP and by the re-expansion of Cyperaceae. The drop in the water table in the peatland is concurrent with warm and dry climate of the Medieval Climatic Anomaly (MCA) in Central Europe (Büntgen et al., 2011). Macrocharcoal fragments found in the peat between ca. 1200 and 950 cal yr BP (Fig. 7) could be regarded as an evidence of a dry climate, especially summers, which favoured fire activity. However, it is most likely that such fires may have been ingnited by humans since the higher macrocharcoal levels also parallel an increase in anthropogenic indicators including the pollen of crops. An increase in human impact during this stage is also documented by the intial rise in $\mathrm{Pb}$ levels and other geochemical elements associated with human activity. During the MCA rapid cultural and political change took place in Europe (Büntgen et al., 2011).

\subsubsection{Wet stage (stage $G$, ca. $750-230$ cal yr BP)}

Anincrease in water level between ca. 750 and 230 cal yr BP is indicated by the reappearance of Chara sp. and Cladium mariscus communites in core BSII and the increased role of Chara communities in the core BSI. Higher water levels in the peatland are also supported by the mollusc assemblages. However, the discontinuous presence of mollusc shells 
can be interpreted as the result of fluctuations in the water level and decreased fossilisation potential of the shells. For example, low water stands, but also decreased $\mathrm{CaCO}_{3}$ precipitation, recorded by decreased number of shells fall within marked solar minima e.g., Wolf (ca. 650 cal yr BP) and Spörer (ca. 500 cal yr BP) (PAGES 2k Consortium, 2013; Fig. 7). Lower solar activity is considered to result in a cooler and usually more humid climate (Mauquoy et al., 2002 and references therein). In addition to the mollusc assembleages, a lowering of the water table during the Spörer Minimum is also supported at the study site by the significant reduction of Chara sp. oospores and Menyanthes trifoliata seeds in core BSI (Fig. 3), species typically growing on the wettest places on peatland (Godwin, 1975). Our reconstruction of palaeohydrological changes during the coolest stages of the LIA agrees with paleohydrological data from ombrotrophic peatlands in north western Poland, where temporal lowering of the water table during the solar minima such as Wolf and Spörer were documented (Gałka et al., 2014, 2016b). A decrease in the water level between ca. 400 and 200 cal yr BP has also been documented in the montane ombrotrophic peat bog of Tăul Muced in northern Romania (Feurdean et al., 2015). However, the continuous presence of Chara sp. a fully submerged macroalgae (Forsberg, 1965), in peat layers accumulated during the LIA in both cores in the BS peatland indicates that the water level was above the peatland surface between ca. 750 and 230 cal yr BP. More humid conditions at the BS peatland during the LIA can be associated with the fact that, in contrast to ombrotrophic peatlandswhose development is strictly associated with rainfall water supply, rich fen is also supplied by groundwater. Our higher water level at the BS peatland druing the LIA agrees with the increase in climate humidity that has been documented in northwestern Europe and Scandinavia (Barber et al., 2004; Charman et al., 2006, Väliranta et al., 2007; Mauquoy et al., 2008). 
A decrease in the water table at the BS peatland at ca. 300 cal yr BP is documented by the disapperance of molluscs and the decrease in the abundance of aquatic plants (Fig. 7). However, there are no significant changes the dominant plant species such as Cladium mariscus and Chara sp., Carex sp. and M. trifoliata. These changes coincided with the most significant climate deterioration during the LIA, namely the Maunder Minimum (ca. 250 cal yr BP) (Wanner et al., 2000). Indicators of human impact including cultivated taxa and coprophilous fungi increased from this time accompanied by changes in forest composition i.e., a decline in Carpinus, Fagus and corresponding increase in Salix, Fraxinus, and Pinus. A decrease in water levels during the Maunder Minimum has been recorded on a wider scale in CE Europe (Gałka et al., 2014, 2016b; Feurdean et al., 2015), thus this change in the hydrology of the BS peatland may be regarded as induced by natural forces.

\subsubsection{Hydrological disturbances and human impact (stages H, I, J, 230 cal yr BP-present)}

An increase in the water level between ca. 150 and 20 cal yr BP led to the reappearence of mollusc shells of species typical of shallow, overgrown reservoirs, i.e., $G$. truncatula and P. planorbis, and damp habitats, i.e., V. antivertigo and Succineidae.

It has been shown that human impact i.e, deforestation, drainage, deposition of pollution, agricultural practices such a mowing and grazing have led to changes in peatland hydrology, vegetation, microorganisms populations and biogeochmical processes (van Diggelen et al., 2006, 2015; Lamentowicz et al., 2015b; Mettrop et al., 2014). However, it has also been shown that limited human activities e.g. cattle grazing, mowing and burning can lead to a reduction in fen biodiversity and that these forms of management can be applied during peatland restoration (Middleton et al., 2006). The most significant human impact on the surroundings of our site was noted during its most recent history and reflected by changes 
in the geochemical (e.g. peak near-surface concentrations of anthropogenically derived trace elements) and mineral magnetic properties (e.g. elevated concentrations and mineral magnetic coarsening) of the profile of core BSI. The north eastern part of the peatland was drained, a railway line was built in the southern part, and the cement factory was established to the south. The above changes could have resulted in decreased water levels, increase in pollution deposition and even favour fire events e.g. in May 2012 fire destroyed ca. 30 ha of the peatland. Despite these various and intense human activities, no marked changes in the local plant communities were recorded. On the contrary, the number of plants increased in the core BSI including the re-appearance of $C$. mariscus in sampling site and the first record of Carex hostiana and Carex flava agg. (Fig. 3).

\subsection{Sensivity of Cladium mariscus to climate changes in SE Poland}

Macro- and microfossils of $C$. mariscus are relatively common in Holocene sediments in Central Europe (Pokorný et al., 2010; Gałka and Tobolski, 2012; Kulesza et al., 2012; Hájková et al., 2013; Gałka et al., 2015; Dobrowolski et al., 2016). However, the range of $C$. mariscus occurrence in Central Europe has decreased in recent centuries due to human activity (drainage), the oligotrophication of habitats and the lack of access to carbonate sediments (Salmina, 2004; Gałka and Tobolski, 2012). Presently C. mariscus is still occurs mainly around outflow depressions, where there is good supply of carbonate ions from the dissolution of the carbonate bedrock (Buczek, 2005), or around lakes as an emerged plant (Namura-Ochalska, 2005; Karcz, 2008; Gałka and Tobolski, 2012) where $\mathrm{Ca}^{2+}$ ions are supplied from dissolution of carbonates in glacial sediments.

In contrast to our expectations of the sensitivity of this species to climate, no clear link between presence warm climatic stages and the variability in the occurrence of $C$. mariscus was observed at BS peatland. The first $C$. mariscus seeds and pollen were recorded 
between 2500 and 2450 cal yr BP in core BS II coincident with the lowering of the water table. The re-appearance of $C$. mariscus pollen at ca. 2050 and 1750 cal yr BP in core BSII coincided with the warm Roman Period. In addition, $C$. mariscus presence was recorded at ca. 1300 cal yr BP in core BS I, which may be linked to the start of the Medieval Climate Anomaly (MCA). The abundant and constant presence of $C$. mariscus pollen in core BS II began at ca. $800 \mathrm{cal} \mathrm{yr} \mathrm{BP}$ and coincided with the end of MCA. On the other hand, the constant presence of $C$. mariscus seeds in core BSII was documented later; from ca. $450 \mathrm{cal}$ yr BP through the climate cooling of the LIA, whereas in core BSI its seeds were present from ca. 100 cal yr BP. It is considered that C. mariscus can tolerate a mean temperature of the coldest month between -4 to $-6{ }^{\circ} \mathrm{C}$ with a warmest month mean between $+16{ }^{\circ} \mathrm{C}$ and $+18{ }^{\circ} \mathrm{C}$ (Jalas and Okko, 1951). Generally, temperatures below $-2{ }^{\circ} \mathrm{C}$ can damage the meristems (Conway 1938), but water can provide insulation, thus allowing the plant to survive at colder temperatures.

Botanical studies conducted in Latvia (Salmina, 2004) and southeartern Poland (Buczek, 2005), and palaeoecological studies conducted in NE Poland (Kłosowski, 1986/87; Gałka and Tobolski, 2012) and in Slovakia (Hájková et al., 2013) have shown a clear link between the occurence of carbonate sediments and $C$. mariscus distribution. Our paleoecological studies at BS peatland are therefore consistent with previous findings suggesting that the presence of carbonate sediments was likely an important limiting factor for this species. Our geochemical studies indicate a relatively high level of $\mathrm{Ca}$ in sediments between ca. 4000-0 cal yr BP, which suddenly dropped in the most recent peat layers. A smaller amount of $\mathrm{Ca}$ in the upper peat layers in core BSI probably reflects a decreased input of groundwater, and therefore a smaller contribution of calcium, from the surrounding peatland. However, the relationship between the occurrence of $C$. mariscus and carbonate sediments reqiures further paleoecological investigation. The expansion of Cladium mariscus 
was preceded by, or concurrent with, periods of increased fragments of macrocharcoal and may suggest a link between its development and burning activity. Geobotanical studies carried out by Buczek (2005) have shown that C. mariscus may survive burning during periods of high water level, because it regenerates rapidly from its submerged rhizomes. Periodic fire prevents accumulation of thick layer of leaf debris that suppresses plant vigour. However, severe fires during dry conditions and lower water levels could kill the rhizomes of C. mariscus thus favouring the penetration of other plant species into Cladium stands (Vaughan, 2012).

Buczek (2005) also suggested that a fall in water level in karst sinkholes, caused by drainage activity between AD 1920 and 1950, could favour expansion of C. mariscus, because previous water levels were too high to provide an appropriate habitat for this plant. The optimal water depth for $C$. mariscus is considered to range between $15 \mathrm{~cm}$ below up to 40 cm above the ground (Vaughan, 2012).

\section{Conclusions}

1. The local vegetation succession in cores BSI and BS II show a a similar trend. Bagno Serebryskie peatland has developed across lake sediments. We identified a shallow lake phase (4000-2000 cal yr BP), initialy dominated by several species of Potamogeton, Ceratophyllum demersum, Stratiotes aloides, followed by Chara spp. and Carex spp. communities. Between 1350 and $900 \mathrm{cal}$ yr BP plant communities of Carex lasiocarpa and Mentha aquatica played a dominant role. Cladium mariscus was identified, based on seeds and pollen, from ca. 1300 cal yr BP in BSI and ca. 2500 cal yr BP in BSII, and with a constant presence from 450 cal yr BP. The occurence of M. aquatica and Carex hostiana is recorded in the most recent period in both cores. 
2. Based on the presence of wethabitat indicators ie., molluscs, plant macrofossils and pollen assemblages we have distinguished five wet periods around: (A) 5000-3300, (C) 2800-2150, (E) 1600-1100, (G) 750-230, (I) 150-10 cal yr BP and five dry periods at ca.: (B) 3300-2800, (D) $2150-1600$, (F) 1100-750, (H) 230-150, (J) 10 to -64 cal yr BP in the peatland's development.

3. Palaeohydrological changes and local plant succession at the study site coincide with regional patterns of climatic change: the expansion of Carex species during the warm and dry Roman Period and Medieval Warm Period, and of Chara species during a cold and humid Litte Ice Age.

4. A clear link between temperature changes and Cladium mariscus population development was not found. However, the expansion of $C$. mariscus was preceeded, and contemporaneous with, periods of more intense local burning (macrocharcoal).

5. The first human activity (deforestation, drainage, fire, dust) in the study area was noted ca. 3200 cal yr BP and increased markedly from 500 cal yr BP (pollen and geochemistry), affecting local plant development including the population size of $C$. mariscus. Our study has shown that despite human impact, the BS peatland has hosted rare, presently protected species, for hundreds of years e.g., C. mariscus.

6. We conclude that, in common with ombrothrophic bogs, rich fen ecosystems can provide a reliable source of palaeoclimatic and palaeohydrological data. Our study also shows that large peatlands (376 ha) can also act as sensitive palaeohydrological archives in a similar way to smaller wetlands.

7. This study sheds light on the behaviour of plants and molluscs over periods of rapid temperature fluctuations at a regional scale; it will also contribute to the improvement of the conservation management of habitats of species, legally protected in the European Union. As 
such, the development of the $C$. mariscus population in BS peatland, and other sites in SE Poland, may be stimulated by climate warming after the Little Ice Age.

\section{Acknowledgments}

Research funded by the National Science Centre, grant no DEC-2013/09/B/ST10/01589 (PI:

Mariusz Gałka). We express our gratitude to Waldemar Gałka, Dawid Gałka, and Andrzej Mazur for assistance in the field work and sediment sampling, Małgorzata Suchorska for assistance in pollen sample preparation.

\section{References}

Akinyemi, F.O., Hutchinson, S.M., Mîndrescu. M., Rothwell. J.J., 2013. Lake sediment records of atmospheric pollution in the Romanian Carpathians. Quat. Inter. 293, 105113.

Alexandrowicz, W.P. 2007. Malakofauna późnoglacjalnych i holoceńskich węglanowych osadów jeziornych północnej Polski. Geologia 33, 395-420.

Alexandrowicz, W.P. 2013. Evolution of the malacological assemblages in North Poland during the Late Glacial and Early Holocene. Folia Quarter. 70, 39-69.

Aleksandrowicz, S.W., Bałaga, K., Dobrowolski, R. 1994. Etapy rozwoju torfowiska kopułowego Krzywice w okolicach Chełma Lubelskiego. Geologia 20, 259-273.

Barber, K.E., Chambers, F.M., Maddy, D., 2004. Late Holocene climatic history of northern Germany and Denmark: peat macrofossil investigations at Dosenmoor, SchleswigHolstein, and Svanemose, Jutland. Boreas 33, 132-144.

Bauer, I.E., Gignac, L.D., Vitt, D.H. 2003. Development of a peatland complex in boreal 
western Canada: lateral site expansion and local variability in vegetation succession and long-term peat accumulation. Can. J. Bot. 81, 833-847.

Bauer, I.E., Vitt, D.H. 2011. Peatland dynamics in a complex landscape: development of a fen-bog complex in the sporadic discontinuous permafrost zone of northern Alberta, Canada. Boreas 40, 714-726.

Behre, K.-E., 1981. The interpretation of anthropogenic indicators in pollen diagrams. Pollen et Spores 23, 225-245.

Berglund, B.E. 1968 Late-Quaternary vegetation in eastern Blekinge, south-eastern Sweden. A pollen-analytical study. II. Post-glacial time. Opera Bot. 12, 1-190.

Berglund, B.E., Ralska-Jasiewiczowa, M., 1986. Pollen analysis and pollen diagrams. In: Berglund, B.E. (Ed.), Handbook of Holocene Palaeoecology and Palaeohydrology. Wiley \& Sons Ltd, Chichester-Toronto, pp 455-484.

Beug, H.-J., 2004. Leitfaden der Pollenbestimmung für Mitteleuropa und angrenzende Gebiete. Verlag Dr. Friedrich Pfeil, München.

Bronk Ramsey C., 2009. Bayesian analysis of radiocarbon dates. Radiocarbon 51, 337-360.

Buczek, A., 2005. Habitant conditions, ecology, resources and protection of saw sedge Cladium mariscus (L.) Pohl. in Lublin Macroregion. Acta Agroph. 9, 1-127.

Büntgen, U., Tegel, W., Nicolussi, K., McCormick, M., Frank, D., Trouet, V., Kaplan, J.O., Herzig, F., Heussner, K.-U., Esper, J., 2011. 2500 years of European climate variability and human susceptibility. Science 331, 578-582.

Cernohorsky, N,, Horsák, M., Cameron, R.A.D., 2010. Land snail species richness and abundance at small scales: the effects of distinguishing between live individuals and empty shells. J. Conchiol. 40, 233-241.

Charman, D.J., Blundell, A., Chiverrell, R.C., Hendon, D., Langdon, P.G., 2006. Compilation of non-annually resolved Holocene proxy climate records: stacked Holocene peatland 
palaeo-water table reconstructions from Northern Britain. Quat. Sci. Rev. 25, 336-350.

Charman, D.J., Hendon, D., Packman, S., 1999. Multiproxy surface wetness records from replicate cores on an ombrotrophic mire: implications for Holocene palaeoclimate records. J. Quat. Sci. 14, 451-463.

Conway, V. 1938. Studies in autoecology of Cladium Mariscus. The New Phytology 37, 254278.

Herzig, F., Heussner, K.-U., Esper, J., 2011. 2500 years of European climate variability and human susceptibility. Science 331, 578-582.

Clarke, S.J., Lynch, A.J.J. 2016. Palaeoecology to inform wetland conservation and management: some experiences and prospects. Mar. Freshwater Res. 67, 695-706.

Dallinger, R., B. Berger, R. Triebskorn-Köhler, Köhler, H., 2001. Shell biology and ecotoxicology. In The biology of terrestrial molluscs. Barker, G. M. (ed) CABI Publishing, Wallingford, 489-525.

Davies, C.E., Moss, D., Hill, M.O., 2004. EUNIS Habitat classification (Revised 2004). Report to the European Environment Agency. European Topic Centre on Nature Protection and Biodiversity, Paris.

Dobrowolski, R., Alexandrowicz, S.W., Bałaga, K., Durakiewicz, T., Pazdur, A., 1999. Badania martwic wapiennych w obrębie źródliskowych torfowisk kopułowych we wschodniej Polsce. In: Geochronologia górnego czwartorzędu Polski w świetle datowań radiowęlowych i luminescencyjnych., Pazdur A, Bluszcz A, Stankowski W, Starkel L, (eds). Wrocław; 179-197.

Dobrowolski, R., Kulesza, P., Łojek, J., Pidek, I., 2015. Origin and evolution of the Bezedna lake-mire complex in the Lublin area (East Poland): a case study for permafrost lakes in karstic regions. J Paleolimnol. 53, 191-213.

Dobrowolski, R., Bałaga, K., Buczek, A., Alexandrowicz, W.P., Mazurek, M., Hałas, S., 
Piotrowska, N., 2016. Multi-proxy evidence of Holocene climate variability in Volhynia Upland (SE Poland) recorded in spring-fed fen deposits from the Komarów site. The Holocene, doi: 10.1177/0959683616640038.

Ellenberg, H., Weber, H.E., Düll, R., Wirth, V., Werner, W., Paulißen, D., 1991. Zeigerwerte von Pflanzen in Mitteleuropa. Scr. Geobot. 18, 1-248.

Feurdean, A., Liakka, J., Vannière, B., Marinova, E., Hutchinson, S.M., Mosburgger, V., Hickler, T., 2013. 12,000-Years of fire regime drivers in the lowlands of Transylvania (Central-Eastern Europe): a data-model approach. Quat. Sci. Rev. 81, 48-61.

Feurdean, A., Gałka, M., Kuske, E., Tantau, I., Lamentowicz, M., Florescu, G., Liakka, J., Hutchinson, S.M., Mulch, A., Hickler, T., 2015. Last millennium hydroclimate variability in the Northern Carpathians (Romania) based on multi-proxy approach. The Holocene 25, 1179-1192.

Forsberg, C., 1965. Environmental conditions of Swedish charophytes. Sym. Bot. Upsal. 18, $1-67$.

Gálová, A., Hájková, P., Petr, L., Hájek, M., Jamrichova, E., 2016. Origin of a boreal birch bog woodland and landscape development on a warm low mountain summit at the Carpathian-Pannonia interface. The Holocene 26, 1112-1125.

Gałka, M., Aunina, L., Tobolski, K., Feurdea, A., 2016a. Development of Rich Fen on the SE Baltic Coast, Latvia, during the Last 7500 Years, Using Paleoecological Proxies: Implications for Plant Community Development and Paleoclimatic Research. Wetlands 36, 689-703.

Gałka, M., Tobolski, K., 2012. Palaeoecological studies on the decline of Cladium mariscus (Cyperaceae) in NE Poland. Ann. Bot. Fenn. 49, 305-318.

Gałka, M., Miotk-Szpiganowicz, G., Goslar, T., Jęśko, M., van der Knaap, O.W., 
Lamentowicz, M., 2013. Palaeohydrology, fires and vegetation succession in the southern Baltic during the last 7500 years reconstructed from a raised bog based on multi-proxy data. Palaeogeogr. Palaeoclimatol. Palaeoecol. 370, 209-221.

Gałka, M., Tobolski, K., Górska, A., Milecka, K., Fiałkiewicz-Kozieł, B., Lamentowicz, M., 2014. Disentangling the drivers for the development of a Baltic bog during the Little Ice Age in northern Poland. Quat. Int. 328-329, 323-337

Gałka M., Bergonzini L., Williamson D., Majule A., Masao C., Huguet A., 2015. Macrofossil evidence of Late Holocene presence of Aldrovanda vesiculosa L. in Central-Eastern Europe (Poland) and East Africa (Tanzania). Quat. Int. 386, 186-190.

Gałka, M., Tobolski, K., Górska, A., Lamentowicz, M., 2016b. Resilience of plant and testate amoeba communities after climatic and anthropogenic disturbances in a Baltic bog in Northern Poland: implications for ecological restoration. The Holocene. DOI: $10.1177 / 0959683616652704$

Godwin, H., 1975. History of the British Flora. A Factual Basis for Phytogeography. Second edition. Cambridge University Press, Cambridge.

Grimm, E.C., 1992. TILIA/TILIA-graph. Version 1.2. Illinois State Museum, Springfield, Illinois.

Grootjans, A.P., Adema, E.B., Bleuten, W., Joosten, H., Madaras, M., Janáková, M., 2006. Hydrological landscape settings of base-rich fen mires and fen meadows: an overview. App. Veg. Sci. 9, 175-184.

Hájek, M., Horsák, M., Hájková, P., Dítě, D., 2006. Habitat diversity of central European fens in relation to environmental gradients and an effort to standardise fen terminology in ecological studies. Persp. Plant Ecol. Evol. Syst. 8, 97-114.

Hájková, P., Jamrichova, E., Horsák, M., Hájek, M., 2013. Holocene history of a Cladium 
mariscus-dominated calcareous fen in Slovakia: vegetation stability and landscape development. Preslia 85, 289-315.

Haliuc, A., Hutchinson, S.M., Florescu, G., Feurdean, A., 2016. The role of fire in landscape dynamics: An example of two sediment records from the Rodna Mountains, northern Romanian Carpathians. Catena 137, 432-440.

Hammer, Ø., Harper, D.A.T., Ryan, P.D. 2001. PAST: Paleontological statistics software package for education and data analysis. Palaeontol. Electr. 4, 1-9.

Hannon, G., Gaillard, M.-J., 1997. The plant macrofossil record of past lake-level changes. J. Paleolimnol. 18, 15-28.

Heiri, O., Lotter, A.F., Lemcke, G., 2001. Loss on ignition as a method for estimating organic and carbonate content in sediments: reproducibility and comparability of results. J. Paleolimnol. 25, 101-110.

Hill, M.O, Bell, N., Bruggeman-Nannenga, M.A., Brugués, M., Cano, M.J., Enroth, J., Flatberg, K.I., Frahm, J.-P., Gallego, M.T., Garilleti, R., Guerra, J., Hedenäs, L., Holyoak, D.T., Hyvönen, J., Ignatov, M.S., Lara, F., Mazimpaka, V., Muñoz, J., Söderström, L., 2006. Bryological Monograph. An annotated checklist of the mosses of Europe and Macaronesia. J. Bryol. 28, 198-267.

Horsák, M., Cernohorsky, N., 2008. Mollusc Diversity Patterns in Central European Fens: Hotspots and Conservation Priorities. J. Biogeogr. 35, 1215-1225.

Horsák, M., Hájek, M., 2003. Composition and species richness of molluscan communities in relation to vegetation and water chemistry in the Western Carpathian spring fens: the poor-rich gradient. J. Moll. Stud. 69, 349-357.

Hua, Q., Barbetti, M., Rakowski, A.J., 2013. Atmospheric Radiocarbon for the Period 19502010. Radiocarbon 55, 2059-2072. 
Hutchinson, S.M. 1995. Use of magnetic and radiometric measurements to investigate erosion and sedimentation in a British upland catchment. Earth Surf. Proc. Land. 20, 293-314. Ilomets, M., Truus, L., Pajula, R. \& Sepp, K. (2010). Species composition and structure of vascular plants and bryophytes on the wate $r$ level gradient within a calcareous fen in North Estonia. Est. J. Ecol. 59: 19-38.

Jalas, J., Okko, V. 1951. Botanical and geological analysis of Cladium mariscus station in Joroinen. Archiv. Soc. Zool. Bot. Fenn. 5, 82-101.

Juggins, S., 2003. C2 User guide. Software for ecological and palaeoecological data analysis and visualisation. University of Newcastle, Newcastle upon Tyne.

Karcz, G., 2008. Kłoć wiechowata Cladium mariscus (L.) i torfowiska nakredowe jako siedlisko priorytetowe Natura 2000 w Pszczewskim Parku Krajobrazowym [The Great Fen Sedge (Cladium mariscus) and mires on chalk substratum as a priority habitat of Natura 2000 in Pszczew Landscape Park]. Stud Lim Tel. 2, 47-53.

Kłosowski, S., 1986/87. Cladietum marisci (All. 1922) Zobrist 1935 w północno-wschodniej Polsce na tle warunków siedliskowych [Das Cladietum marisci (All. 1922) Zobrist 1935 in nord-ostlichen Teil Polens und seine Standortverhältnisse]. Frag. Flor. Geobot. XXXI-XXXII, 207-223.

Kołaczek, P., Gałka, M., Karpińska-Kołaczek, M., Lutyńska, M., 2015. Late Pleniglacial and Late Glacial lake-mire transformations in south-eastern Poland reflected in aquatic and wetland vegetation changes. Quat. Int. 388, 39-50.

Kotowski, W., Jabłońska, E., Bartoszuk, H., 2013. Conservation management in fens: Do large tracked mowers impact functional plant diversity?. Biol. Conser. 167, 292-297.

Krassowska, A., Niemczycka, T., 1984. Pokrywa mezozoiczna Lubelskiego Zagêbia Węglowego. Przewodnik LVI PTGeol. w Lublinie, 36-55.

Kulesza, P., Suchora, M., Pidek, I.A., Dobrowolski, R., Alexandrowicz, W.P. 2012. The 
Holocene palaeoenvironmental changes reflected in the multi-proxy studies of Lake Słone sediments (SE Poland). Palaeogeogr. Palaeoclimatol. Palaeoecol. 363-364, 7998.

Lamentowicz, M., Gałka, M., Milecka, K., Tobolski, K., Lamentowicz, Ł., FiałkiewiczKozieł, B., Blaauw, M., 2013. A 1300 years multi-proxy, high-resolution record from a rich fen in northern Poland: reconstructing hydrology, land-use and climate change. J. Quat. Sci. 28, 582-594.

Lamentowicz, M., Gałka, M., Pawlyta, J., Lamentowicz, Ł., Goslar, T., Miotk-Szpiganowicz, G., 2011. Climate change and human impact in the southern Baltic during the last millennium reconstructed from an ombrotrophic bog archive. Studia Quart. 28, 3-16. Lamentowicz M., Gałka M., Lamentowicz, Ł., Obremska, M., Kühl, N., Lücke, A., Jassey, V.E.J., 2015a. Reconstructing climate change and ombrotrophic bog development during the last 4000 years in northern Poland using biotic proxies, stable isotopes and trait-based approach. Palaeogeogr. Palaeoclimatol. Palaeoecol. 41, 261-277.

Lamentowicz, M., Mueller, M., Gałka, M., Barabach, J., Milecka, K., Goslar, T., Binkowski, M., 2015b. Reconstructing human impact on peatland development during the past 200 years in CE Europe through biotic proxies and X-ray tomography. Quat. Int. 357, 282-294.

Lorenc H. (red.), 2005. Atlas klimatu Polski, Instytut Meteorologii i Gospodarki Wodnej, Warszawa.

Ložek, V., 1964. Quartärmollusken der Tschechoslowakei. Rozpravy Ústředního Ústavu Geologického 31, 1-374.

Ložek, V., 2000. Palaeoecology of Quaternary Mollusca. Sobornik geologickych ved, Antropozoikum 24, 35-59. 
Magny, M., 2004. Holocene climate variability as reflected by mid-European lake-level fluctuations and its probable impact on prehistoric human settlements. Quat. Int. 113, $65-79$.

Mälson, K., Rydin, H., 2007. The regeneration capabilities of bryophytes for rich fen restoration. Biol. Conserv. 113, 435-442.

Marcisz, K., Colombaroli, D., Jassey, V.E.J., Tinner, W., Kołaczek, P., Gałka, M., KarpińskaKołaczek, M., Słowiński, M., Lamentowicz, M., 2016. A novel testate amoebae traitbased approach to infer environmental disturbance in Sphagnum peatlands. Sci. Rep. 6, 33907. http://dx.doi.org/10.1038/srep33907.

Mauquoy, D., van Geel, B., Blaauw, M., van der Plicht, J., 2002. Evidence from northwest European bogs shows 'Little Ice Age' climatic changes driven by variation in solar activity. Holocene 12, 1-6.

Mauquoy, D., Yeloff, D., van Geel, B., Charman, D., Blundell, A., 2008. Two decadally resolved records from north-west European peat bogs show rapid climate changes associated with solar variability during the mid-late Holocene. J. Quat. Sci. 23, 745-763.

Mettrop, I.S., Cusell, C., Kooijman, A.M., Lamers, L.P.M., 2014. Nutrient and carbon dynamics in peat from rich fens and Sphagnum fens during different gradations of drought. Soil Biol. Biochem. 68, 317-328.

Middleton, B.A., Holsten, B.R., van Diggelen, R., 2006. Biodiversity management of fens and fen meadows by grazing, cutting and burning. Appl. Veg. Sci. 9, 307-316.

Mirek, Z., Pięknoś-Mirkowa, H., Zając, A., Zając, M., 2002. Flowering Plants and Pteridophytes of Poland. A checklist. IB PAN, Kraków.

Mooney, S.D., Tinner, W., 2011. The analysis of charcoal in peat and organic sediments. 
Mires and Peat 7: Art. 9. (Online: http://www.mires-andpeat.net/pages/volumes/map07/map0709.php).

Moore, P.D., Webb, J.A., Collinson, M.E., 1991. Pollen Analysis. Blackwell Scientific

Publications, Oxford.

Namura-Ochalska, A., 2005. Contribution to the characteristic of Cladium mariscus (L.) Pohl population in the initial zone of floating mat on an oligo-humotrofic lake in northeastern Poland. Acta Soc. Bot. Pol. 74, 167-173.

PAGES 2k Consortium, 2013. Continental-scale temperature variability during the last two millennia. Nat. Geosci., 6, 339-346.

Pełechaty M., Pukacz A., 2008. Klucz do oznaczania gatunków ramienic (Characeae) w rzekach i jeziorach. Biblioteka Monitoringu Środowiska, Warszawa 80pp.

Piechocki, A., 1979. Mięczaki (Mollusca). Ślimaki (Gastropoda). Państwowe Wydawnictwo Naukowe, Warsaw-Poznań.

Pokorný, P., Sáldo, J., Bernardowá, A., 2010. Holocene history of Cladium mariscus (L.) Pohl in the Czech Republic. Implications for species population dynamics and palaeoecology. Acta Palaeobot. 50, 65-76.

Reimer, P.J., Bard, E., Bayliss, A., Beck, J.W., Blackwell, P.G., Ramsey, C.B., Buck, C.E., Cheng, H., Edwards, R.L., Friedrich, M., Grootes, P.M., Guilderson, T.P., Haflidason, H., Hajdas, I., Hatté, C., Heaton, T.J., Hoffmann, D.L., Hogg, A.G., Hughen, K.A., Kaiser, K.F., Kromer, B, Manning, S.W., Niu, M., Reimer, R.W., Richards, D.A., Scott, E.M., Southon, J.R., Staff, R.A., Turney, C.S.M., van der Plicht, J., 2013. IntCal13 and Marine13 radiocarbon age calibration curves 0-50,000 years cal. BP. Radiocarbon 55, 1869-1887.

Salmina, L., 2004. Factors influencing distribution of Cladium mariscus in Latvia. Ann. Bot. Fenn. 41, 367-371.

Santisteban, J.I., Mediavilla, R., Lopez-Pamo, E., Dabrio, C.J., Zapata, M.B.R., Garcia, 
M.J.G., Castano, S., Martinez-Alfaro, P.E., 2004. Loss on ignition: a qualitative or quantitative method for organic matter and carbonate mineral content in sediments? J. Paleolimnol. 32, 287-299.

Seddon, A.W.R., Mackay, A.W., Baker, A.G. et al., 2014. Looking forward through the past: identification of 50 priority research questions in palaeoecology. J Ecol. 102, 256-267.

Shuttleworth, E.L., Evans, M.G., Hutchinson, S.M., Rothwell, J.J., 2014. Assessment of lead contamination in peatlands using field portable XRF. Water, Air, and Soil Poll. 225: 1844 doi:10.1007/s11270-013-1844-2.

Slack, N.G., Vitt, D.H., Horton, D.G., 1980. Vegetation gradients of minerotrophically rich fens in western Alberta. Can. J. Bot. 58, 330-350.

Słowiński, M., Marcisz; , K., Płóciennik, M., Obremska, M., Pawłowski, D., Okupny, D., Słowińska, S., Borówka, R., Kittel, P., Forysiak, J., Michczyńska, D.J., Lamentowicz, M., 2016. Drought as a stress driver of ecological changes in peatland - a palaeoecological study of peatland development between $3500 \mathrm{BC}$ and $200 \mathrm{BC}$ in central Poland. Palaeogeography, Palaeoclimatology, Palaeoecology 461, 272-291.

Starkel, L., Michczyńska, D., Krapiec, M., Margielewski, W., Nalepka, D., Pazdur, A., 2013. Progress in the holocene chrono-climatostratigraphy of Polish territory. Geochronometria 40, 1-21.

Swindles, G.T., Plunkett, G., Roe, H.M., 2007. A delayed climatic response to solar forcing at 2800 cal. BP: multiproxy evidence from three Irish peatlands. The Holocene 17, 177-182.

Swinehart, A.L., Parker, G.R. 2000. Palaeoecology and development of peatlands in Indiana. Am. Midl. Nat. 143, 267-297. 
Väliranta, M., Korhola, A., Seppä, H., Tuittila, E.-S., Sarmaja-Korjonen, K., Laine, J. and Alm, J., 2007. High-resolution reconstruction of wetness dynamics in a southern boreal raised bog, Finland, during the late Holocene: a quantitative approach. Holocene 17, 1093-1107.

van Diggelen, R., Middleton, B., Bakker, J., Grootjans, A. \& Wassen, M. 2006. Fens and floodplains of the temperate zone: Present status, threats, conservation and restoration App. Veg. Sci. 9, 157-162.

van Diggelen, J.M.H., Bense, I.H.M., Brouwer, E., Limpens, J., van Schie, J.M.M., Smolders, A.J.P., Lamers, L.P.M., 2015. Restoration of acidified and eutrophied rich fens: Longtermeffects of traditional management and experimental liming. Ecol. Engin. 75, 208216.

van Geel, B., Bohncke, S.J.P., Dee, H., 1981. A palaeoecological study ofan upper Late Glacial and Holocene sequence from "De Borchert", The Netherlands. Rev. Palaeobot. Palynol. 31, 367-448.

van Geel, B., Heijnis, H., Charman, D.J., Thompson, G., Engels, S., 2014. Bog burst in the eastern Netherlands triggered by the $2.8 \mathrm{kyr}$ BP climate event. The Holocene 24, 1465-1477.

Vaughan, G., 1992. Cladium mariscus L.(Pohl.) In: Brink M., Achigan Dako E. G. (ed.). Plant resources of Tropical Africa, 16. Fibres. Prota Foundation, Wageningen, Netherlands. CTA/Wageningen, Netherlands, pp. 85-88.

Walter, H, Straka, H., 1970. Arealkunde. Floristisch-historische Geobotanik. Verlag Eugen Ulmer, Stuttgart.

Wanner, H., Holzhauser, H. P., Pfister, C., and Zumbühl, H., 2000. 'Interannual to Century Scale Climate Variability in the European Alps'. Erdkunde 54, 62-69.

Wanner, H. Solomina O., Grosjean M., Ritz SP., Jetel M., 2011. Structure and origin of 
Holocene cold events. Quat. Sci. Rev. 30, 3109-3123.

Wäreborn, I., 1970. Environmental factors influencing the distribution of land molluscs of an oligotrophic area in southern Sweden. Oikos 21, 285-291.

Welter-Schultes, F.W., 2012. European non-marine molluscs, a guide for species identification. Bestimmungsbuch für europäische Land- und Süsswassermollusken. Planet Poster Editions, Göttingen. 674 pp.

Wojtanowicz, J., 1994. O termokrasowej genezie jezior łęczyńsko-włodawskich. Ann. Univer. Mar. Curie Sklod. Sect B 49, 1-18.

Yu, Z., 2006. Holocene carbon accumulation of fen peatlands in boreal western Canada: A complex ecosystem response to climate variation and disturbance. Ecosystems 9, 1278-1288.

Zarzycki, K., Trzcińska-Tacik, H., Różański, W., Szeląg, Z., Wołek, J., Korzeniak, U., 2002. Ecological indicator values of vascular plants of Poland. Biodiversity of Poland, Kraków. 


\section{Description of figures:}

Fig. 1. A. Site location in Central Europe (source: http://pl.wikipedia.org/w/index.php?title=Plik:Europe_topography_map.png\&filetimestamp= 20080612084157, Author: San Jose; modified) and B. the location of sites (black triangles) cited in the text: 1) Kontolanrahka bog (Väliranta et al., 2007), 2) Männikjärve bog, Estonia (Sillasoo et al., 2007); 3) Apšuciems Mire (Gałka et al., 2016), 4) Dosenmoor bog (Barber et al., 2014), 5) Bagno Kusowo bog (Lamentowicz et al., 2015), 6) Stążki fen (Lamentowicz et al., 2011), 7) Gązwa bog (Gałka et al., 2015), 8) Lake Purwin (Gałka and Apolinarska, 2014), 9) Radzików spring-fedfen (Dobrowolski et al., 2012), 10) Lake Słone (Kulesza et al., 2012), 11) Krzywce spring-fedfen (Dobrowolski et al., 1999), 12) Komarów spring-fedfen (Dobrowolski et al., 2016), 13) Male Bielice spring-fedfen (Hájková et al., 2013), 14) Taul Muced bog (Feurdean et al., 2015).

Fig. 2. Age-depth models of the peat profiles in Bagno Serebryskie: A) Core BSI; B) Core BSII.

Fig. 3. Plant macrofossils showing the local plant succession in Bagno Serebryskie: A) Core BSI; B) Core BSII. Taxa with (\%) are estimated volume percentages, others are counts (with $\mathrm{X}$-axis scale labels; note scale differences). $5 \%$ times exaggeration in grey.

Fig. 4. Selected taxa of pollen, spores and palynomorphs representing regional and local plant succession in Bagno Serebryskie peatland in core BSII. Percentages are shown in black; 5\% times exaggeration in grey. Analysed by Piotr Kołaczek.

Fig. 5. Local mollusc succession in Bagno Serebryskie peatleand in core BSII. Analysed by Karina Apolinarska.

Fig. 6. Selected results of the geochemical analysis of core BSI.

Fig. 7. Comparison of selected curves of palaeoecological data from Bagno Serebryskie peatland with climatic events. Cooling periods: 1) 2.8 ka event, 2) Celtic Expansion, 3) 
Roman Conquest, 4) Migration Period, 5) no name, 6) Oort Minimum, 7) Wolf Minimum, 8)

Spörer Minimum, 9) Maunder Minimum, 10) Dalton Minimum, 11) no name. Curve of solar activity according to Mauquoy et al. (2008).

\section{Description of table}

Table 1. Radiocarbon dates from Bagno Serebryskie core BSI and BSII. 


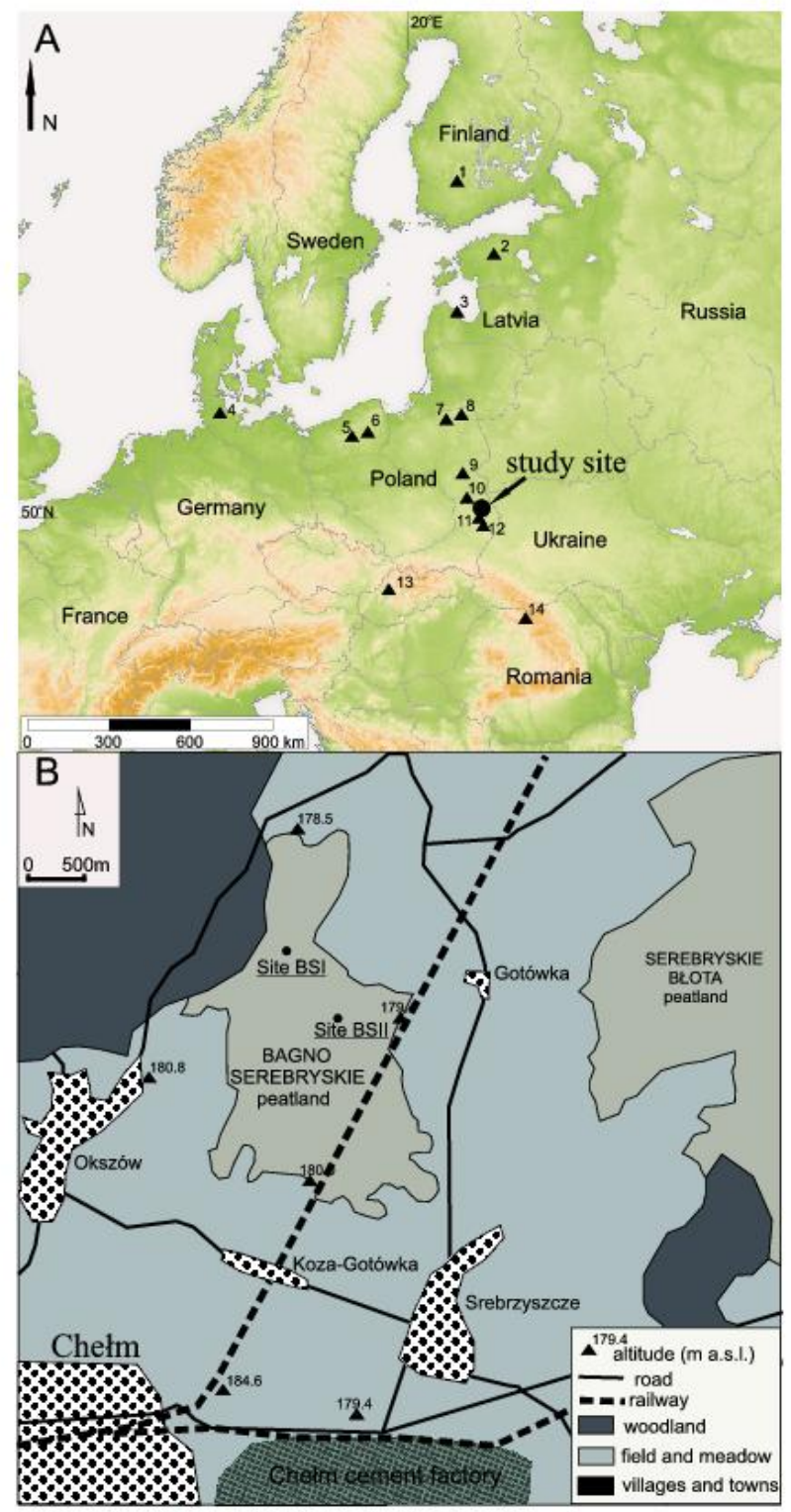

Figure 1 

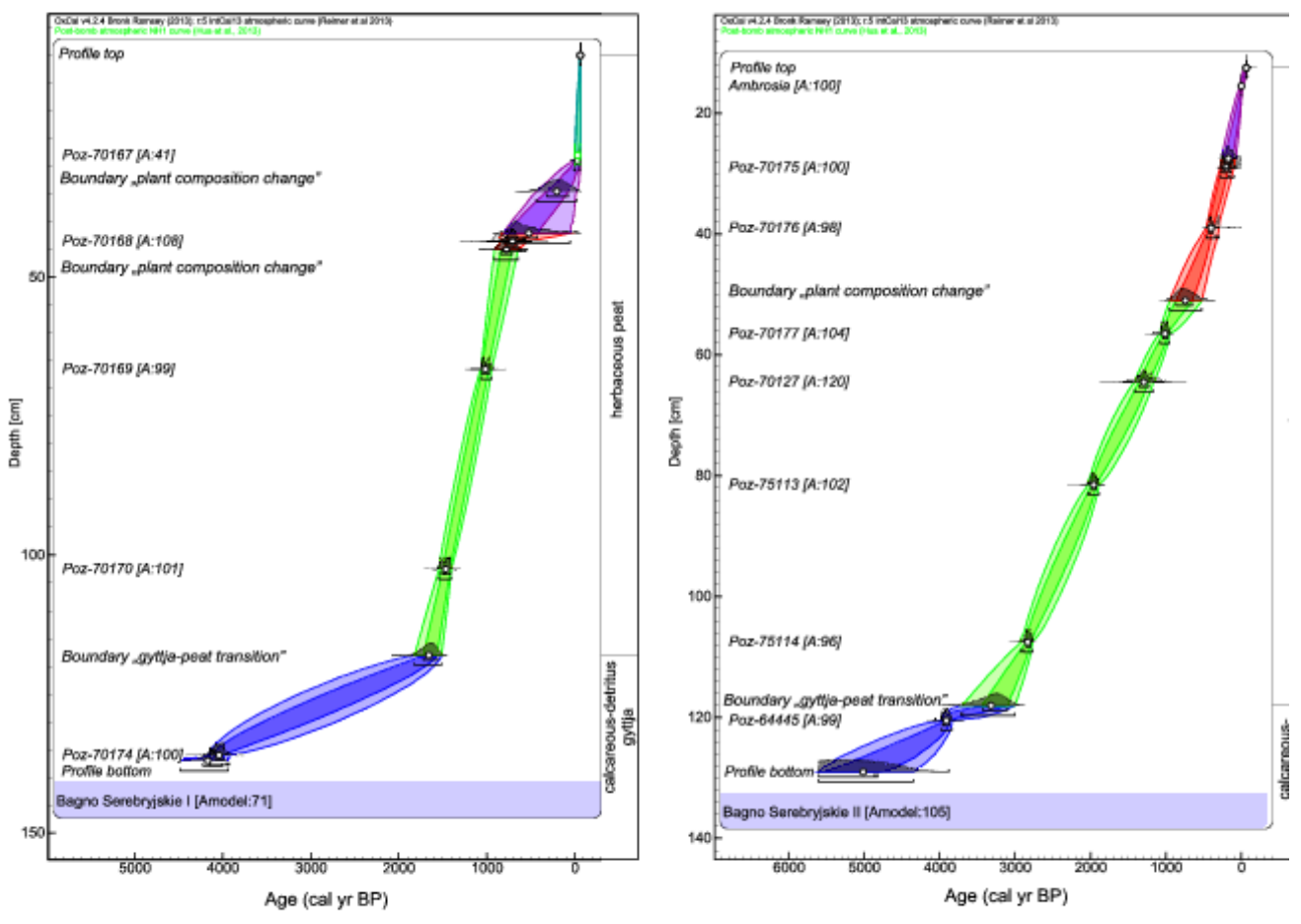

Figure 2 

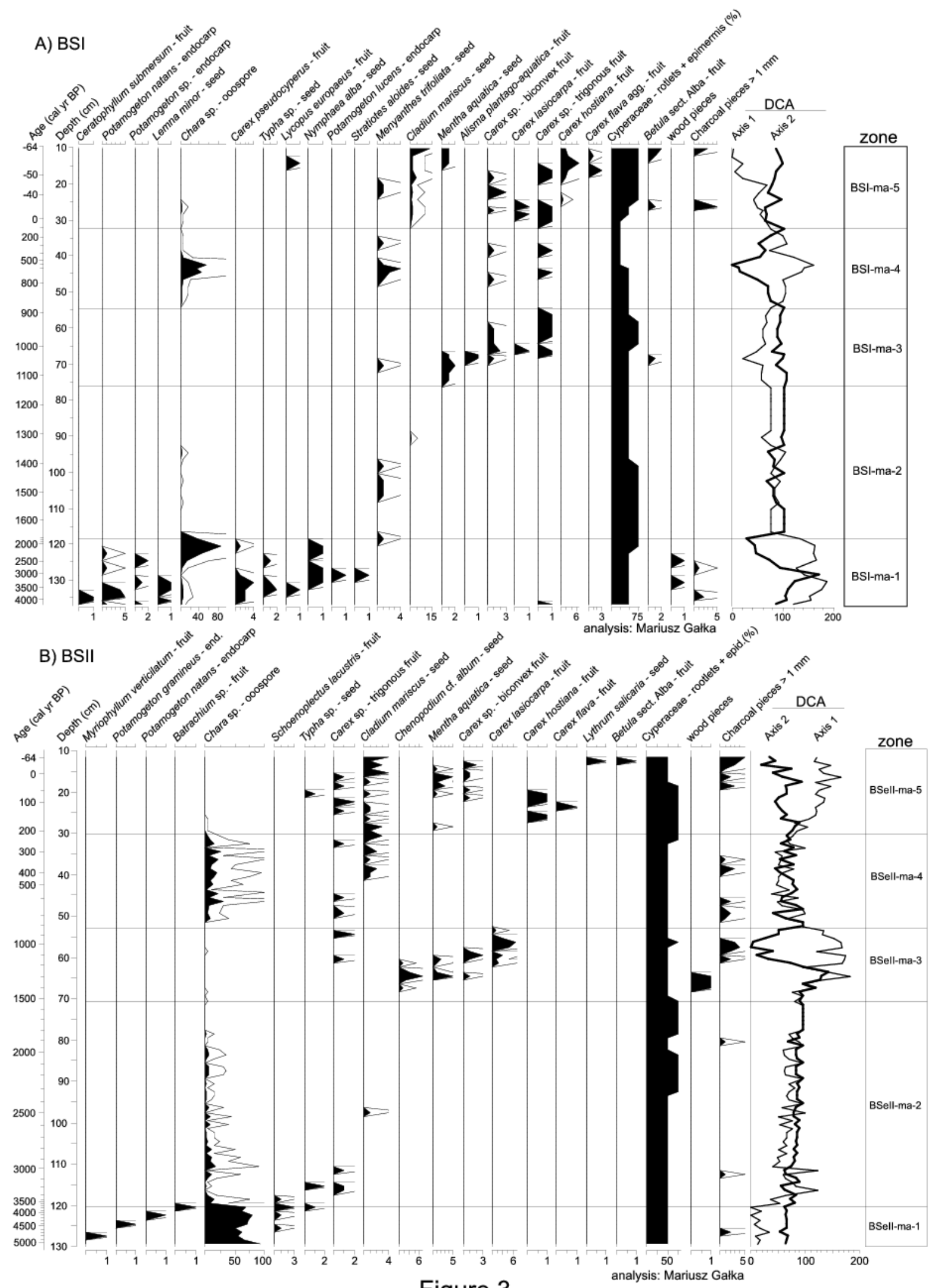

Figure 3 


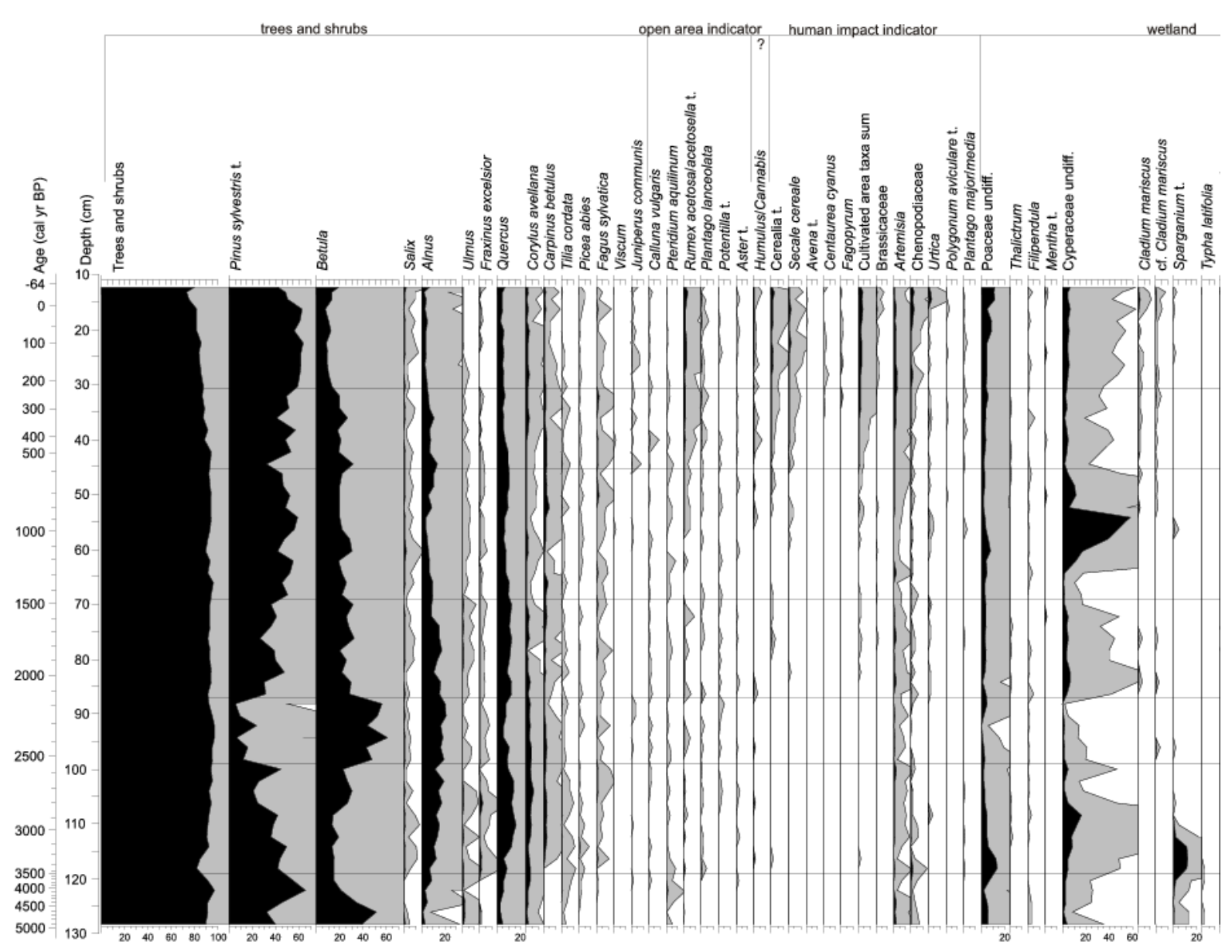

Figure 4 
Bagno Serebryskie, core II mollusc

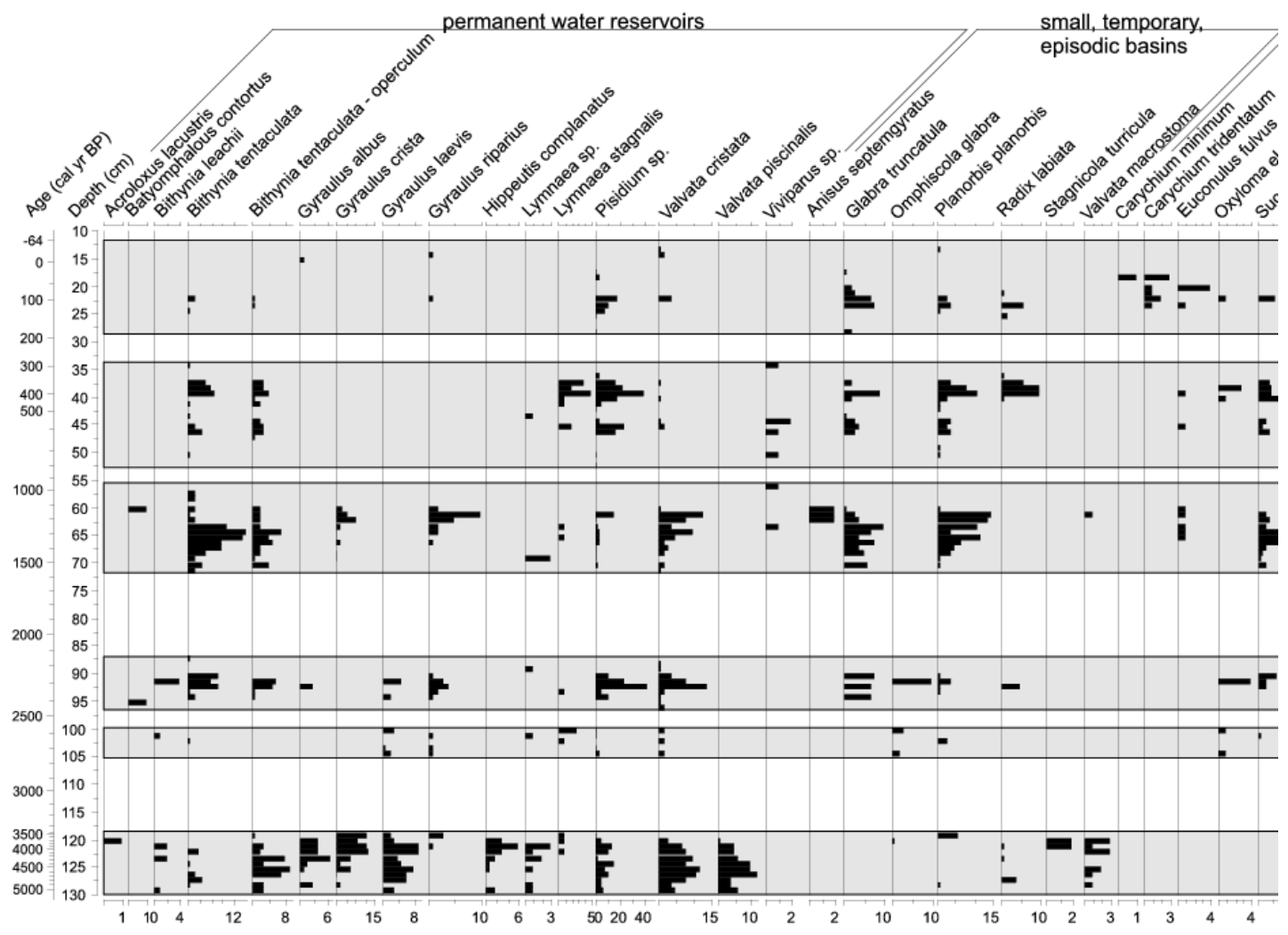

Figure 5 
BSI

geochemical analysis

analysis: Simon Hutchinson

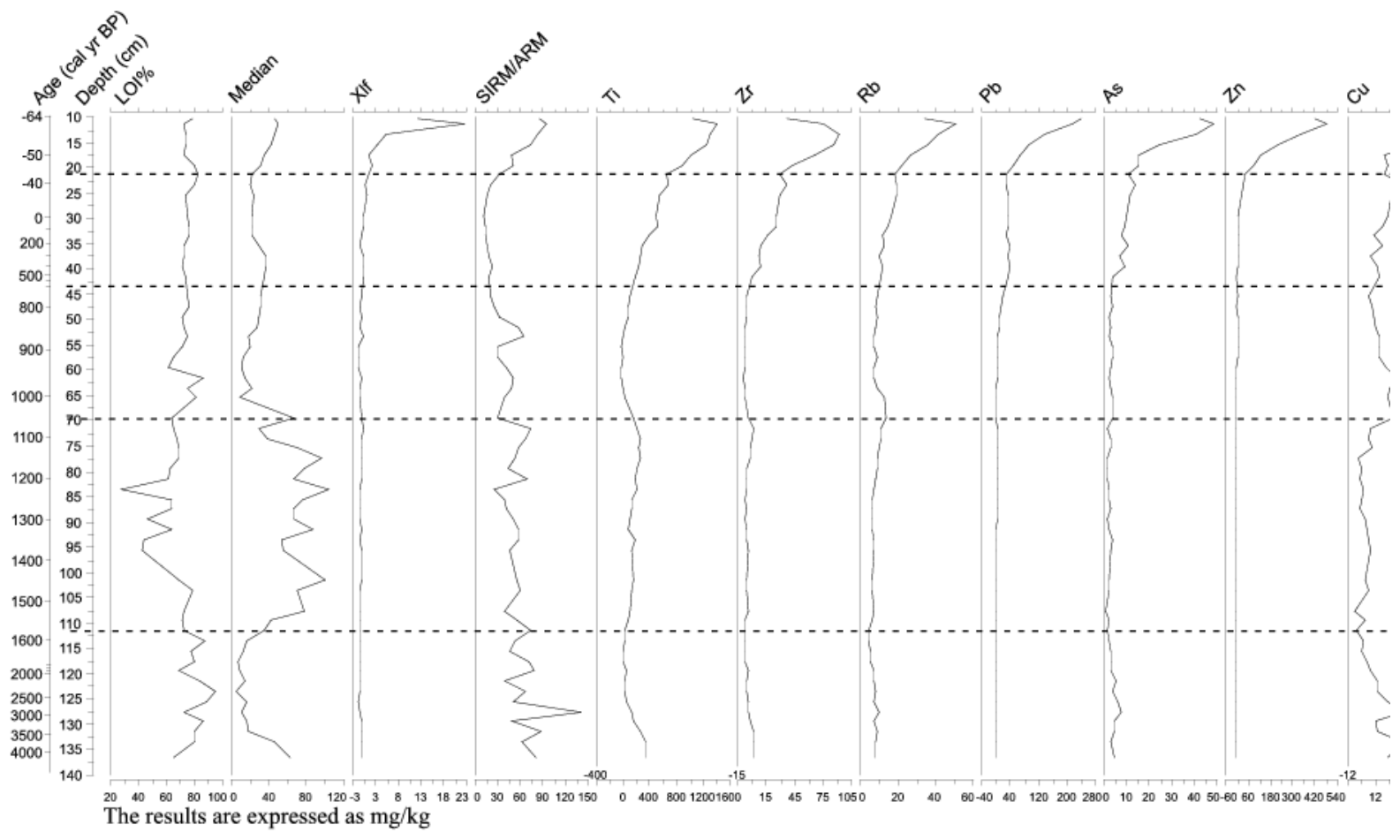

Figure 6 


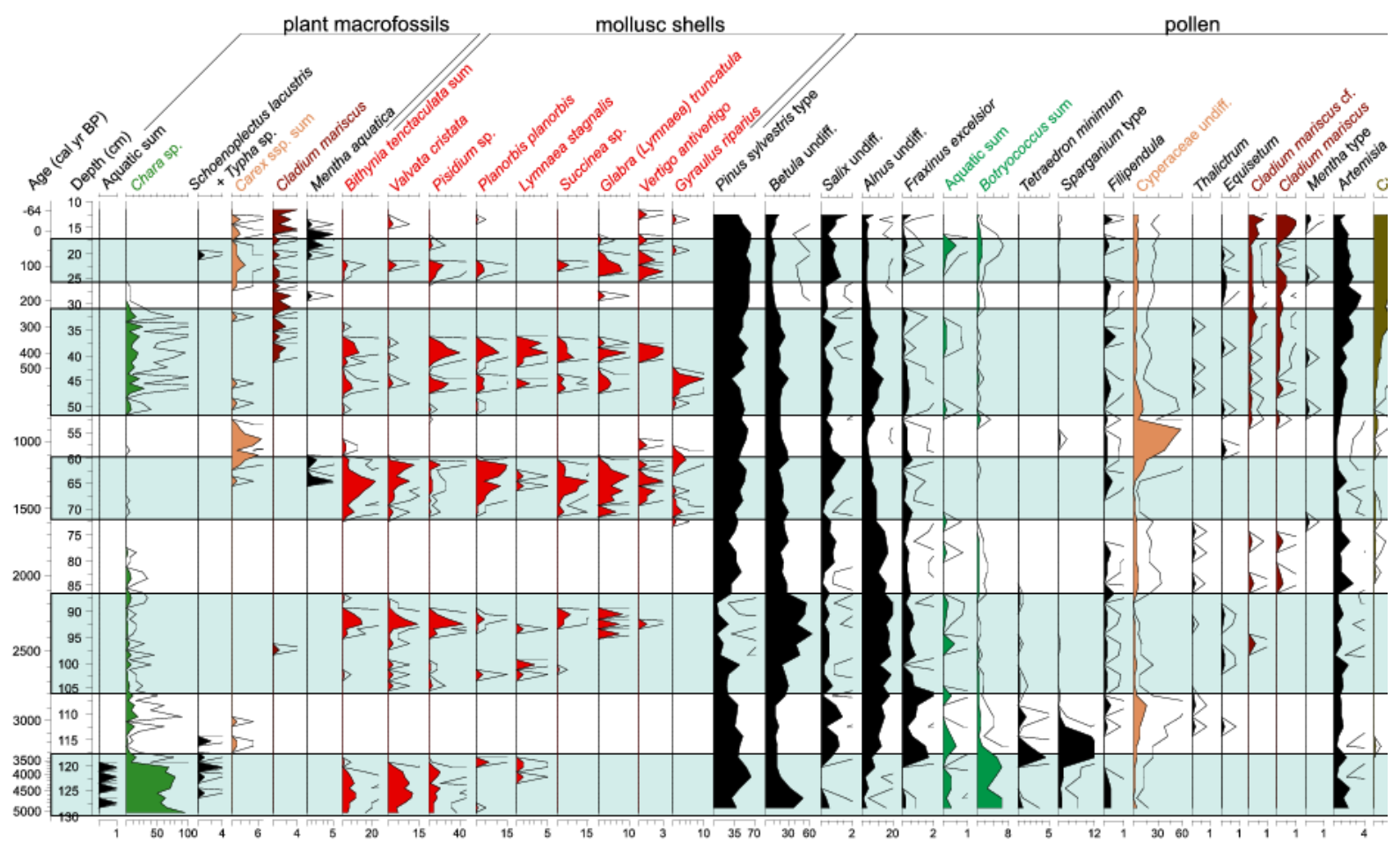

Figure 7 
Table 1. Radiocarbon dates from Bagno Serebryskie, core BSI and BSII.

\begin{tabular}{|c|c|c|c|c|}
\hline $\begin{array}{l}\text { Site/Depth } \\
{[\mathrm{cm}]}\end{array}$ & Material & $\begin{array}{l}\text { Lab. code - } \\
\text { number }\end{array}$ & $\begin{array}{l}\text { C14 date } \\
{[\mathrm{BP}]}\end{array}$ & $\begin{array}{l}\text { Age [cal yr BP] } \\
(95.4 \%)\end{array}$ \\
\hline $\mathrm{BSI} / 27-29$ & $\begin{array}{l}3 \text { seeds of Cladium mariscus, } \\
2 \text { fruits of Carex lasiocarpa, } 1 \\
\text { fruits of Carex sp. }\end{array}$ & Poz-70167 & $\begin{array}{l}105.5 \pm \\
0.34 \mathrm{pMC}\end{array}$ & $\begin{array}{l}-6-59 \\
(3.4 \%) \\
-55(1.4 \%) \\
>-56(90.6 \%)\end{array}$ \\
\hline $\mathrm{BSI} / 43-44$ & $\begin{array}{l}4 \text { seeds of Menyanthes } \\
\text { trifoliata }\end{array}$ & Poz-70168 & $810 \pm 30$ & $781-681$ \\
\hline BSI/66-67 & $\begin{array}{l}3 \text { fruits of Carex sp, } 1 \text { fruits of } \\
\text { Carex lasiocarpa, } 1 \text { seed of } \\
\text { Menyanthes trifoliata }\end{array}$ & Poz-70169 & $1090 \pm 30$ & $1058-936$ \\
\hline BSI/102-103 & $\begin{array}{l}1 \text { seed of Menyanthes } \\
\text { trifoliata, undefinited epiderm }\end{array}$ & Poz-70170 & $1590 \pm 30$ & 1545-1409 \\
\hline BSI/135-137 & $\begin{array}{l}2 \text { fruits of Carex } \\
\text { pseudocyperus, } 1 \text { fruit of } \\
\text { Carex sp. }\end{array}$ & Poz-70174 & $3705 \pm 35$ & $\begin{array}{l}4150-3965(92.9 \%) \\
3945-3929(2.5 \%)\end{array}$ \\
\hline BSII/28-30 & 3 seeds of Cladium mariscus & Poz-70175 & $140 \pm 30$ & $\begin{array}{l}281-170(43.1 \%) \\
153-59(36.6 \%) \\
42-6(15.5 \%)\end{array}$ \\
\hline $\mathrm{BSII} / 38-40$ & $\begin{array}{l}3 \text { seeds of Cladium mariscus, } \\
\text { charcoal }\end{array}$ & $\mathrm{Poz}$ & $285 \pm 30$ & $\begin{array}{l}457-348(60.9 \%) \\
335-286(34.1 \%) \\
162-159(0.4 \%) \\
\end{array}$ \\
\hline BSII/56-57 & 7 fruits of Carex lasiocarpa & Poz-7 & $1120 \pm 30$ & $\begin{array}{l}1173-1160(1.7 \%) \\
1141-1135(0.5 \%) \\
1124-1109(1.4 \%) \\
1088-956(91.8 \%) \\
\end{array}$ \\
\hline BSII/64-65 & $\begin{array}{l}5 \text { seeds of Mentha aquatica, } 1 \\
\text { fruit of Carex sp., } 6 \text { seeds of } \\
\text { Chenopodium sp. }\end{array}$ & Poz-70127 & $1360 \pm 100$ & $\begin{array}{l}1520-1458(4.2 \%) \\
1437-1434(0.2 \%) \\
1421-1059(91.1 \%) \\
\end{array}$ \\
\hline BSII/81-82 & Bulk (decomposed peat) & Poz-75113 & $2015 \pm 30$ & 2044-1889 \\
\hline BSII 107-108 & Bulk (decomposed peat) & Poz-75114 & $2735 \pm 30$ & $\begin{array}{l}2971-2912(0.9 \%) \\
2881-2763(94.5 \%)\end{array}$ \\
\hline BsII/120-121 & $\begin{array}{l}3 \text { fruits of Scheonoplectus } \\
\text { lacustris }\end{array}$ & Poz-64445 & $3610 \pm 30$ & $\begin{array}{l}4059-4054(0.5 \%) \\
3985-3838(94.9 \%) \\
\end{array}$ \\
\hline
\end{tabular}




\section{Highlights}

- Long-term perspective on fen palaeohydrology in CE Europe.

- Rich fen ecosystems can provide a reliable source of palaeoclimatic and palaeohydrological data

- Bagno Serebryskie rich fen preserve the remains of pristine biodiversity despite drainage and fire events 